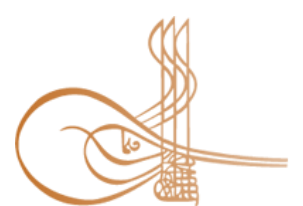

www.turkishstudies.net/social
Turkish Studies - Social Sciences

eISSN: $2667-5617$

Research Article / Araștırma Makalesi

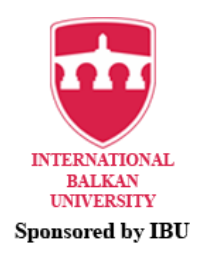

Sponsored by IBU

\title{
20. Yüzyıla Ait Bir Güfte Mecmuasının İncelenmesi
}

\author{
An Analysis of the Lyrics Journal one of the 20th Century
}

\author{
Gamze Köprülü*
}

\begin{abstract}
Lyrics journals are cultural treasures that carry the past to the future, convey the deep-rooted and ancient music culture of the century to which we belong and have a historical document feature for the field of Historical Musicology. The lyrics journals are the sources from which the straight narrated music forms in the edvar books find a kind of life and shape. Since the 15th century, a large number of words were published. While many of these works have contributed to the academic field in today's Turkish, it is also known that there are many more lyrics journal waiting to be worked on the dusty shelves of libraries. 60-0052 inventory registered in Tokat Mevlevihane Museum, the year of writing of the journal which is unknown by whom $\mathrm{h}$. April 25, $1331 \mathrm{~m}$. Is May 8, 1915. All of the works in the journal written with the Rika line are in Turkish. There are 307 works in Turkish, all of which are composed of music, forms such as composition, yürüksemâi,, ağırsemâî, ghazal, song, maqams such as Hicaz, Kürdîlihicazkâr, Sûzinak, and hafif, çenber, aksak and düyek. It is written in the period of study is intended to demonstrate the musical culture is composed situated in magazines Turkey Radio and Television Corporation (TRT) are numbered according to the Archives. TRT Archive record of some of the compositions in Mecmua was not found. The latinizing method was applied to the words in the journal, and the names of the methods, authorities, forms, and composers identified were titled and other findings included in these titles were tried to be beneficial to the field in terms of Systematic Musicology needs.
\end{abstract}

Structured Abstarct: Lyrics journals are self-contained sources belonging to Turkish music. These works, which are among the historical musicology sources and have the characteristics of historical documents, contain valuable information about the rooted musical culture of the period in which they were written. It is possible to access many other information such as sound system, rhythm, maqam, theoretical knowledge, verses, hadiths, poems and historical events of the period in connection with the period in which it was written. This lyrical journal Tokat Mevlevîhâne Museum we are working with is registered with an inventory number of 60-0052 and there is no information about who the author is. The year of writing h. April 25, 1331, m. It is May 8, 1915. It is written in black and white ink with a legible rica handwriting and black ink, which is completely in Turkish, and is $19 \times 13 \mathrm{~cm}$ in size. It is bounded with a burgundy-colored leather coating. As a ornament, the frame which resembles the edict paper model drawn with a black pencil, is drawn on cream colored paper. Journals many pages are missing and empty. In the study, it was aimed to reveal the musical structure of the period in which the journal was written and the information that it would offer us. Answers to the questions about which century the journal belonged to, what rhythms, authorities, composers, musical forms, and theoretical information could be determined were tried to be reached in the light of these answers.

\footnotetext{
* Dr. Öğr. Üyesi, Tokat Gaziosmanpaşa Üniversitesi, Devlet Konservatuvarı, Türk Müziği Bölümü. Asst. Prof Dr. Tokat Gaziosmanpaşa University, State Conservatory, Turkish Music Department. ORCID 0000-0002-6354-3999 gamze.koprulu@gop.edu.tr

Cite as/ Atıf: Köprülü, G. (2020). 20. Yüzyıla ait bir güfte mecmuasının incelenmesi. Turkish Studies - Social, 15(5), 2587-2609. https://dx.doi.org/10.47356/TurkishStudies.44355

Received/Geliş: 19 June/Haziran 2020

Accepted/Kabul: 20 August/Ağustos 2020

Copyright (C INTAC LTD, Turkey
} 
Looking at the lyrical journals spelling periods, it is seen that it dates back to the 15 th century. This work, which was written in the 15th century, and perhaps as the first word journal, can be considered as Nuruosmaniye Ktp., Nr. Registered in 3135 and by Recep Uslu XV. A Mecmua-i Güfte (Nuruosmaniye Ktp., Nr. 3135) or Sultan II. This manuscript, which is studied as a Source of Murad Age Music, can be considered as the first Turkish lyric journal. "The first printed lyrical jounal is the journal that was named" Evterpi "in 1830s and was published in Karaman." (Behar, 2006: 39) Many lyrical journals have been put forth academically in works such as books, articles, papers. The books of Mecmua-i Güfte of Musiki-Şems-i Rumi, Derviş Mehmed El-Mevlevi, lyric journal (Mirac and Ayin journal), Derviş Avni Güfte and Poetry journal are examples of books. Among the works written as an article, the examination of lyrical journal belonging to Hâfiz Abdülbâkî dated 1774, Writing Lyric journals and the Importance of Ottoman Music History in History, An Evaluation on Ottoman Lyric Journal, XVIIT. Articles titled A Lyric Journal Review of the 21st Century can be listed. Some other academic studies such as thesis and papers are included in the article. In this study, which is included in historical musicology, the methods in the report titled "Determinations on Lyric Journal and Examination Principles in Turkish Music Education History" were taken as basis. In the qualitative study in which the due diligence was made according to these methods, the findings such as rhythm, maqam, form, composer, and composer were classified as titles in accordance with the systematic musicology rules and made useful in the field of musicology by applying the latinized method. Archives in the table numbers in the archives of Turkey Radio and Television Corporation (TRT) are numbered. Nine different music forms in the journal, namely, heavy, composing, gazel, köçekçe, methiye, nazire, song, Rumeli folk song, yürüksemai; twelve different maqams, namely acemaşîran, composing, hicaz, hicazkar- kurdilihicazkar, hüseyni, hüzzam, karcığar, nihavend, rast, suzinak, uşşak; aksak- heavyaksak- quickaksak, aksaksemai, curcuna, çenber, çiftesofyan, devrihindi, düyek-heavydüyek, hafif, katakofti, semai, sofyan, Türkaksağı, yürüksemai- senginsemai thirteen different rhythms the journal includes 307 compositions. A separate section is reserved for gazel form. Although there are names of composers and rhythms on some pages, it was seen that lyric was not given. Lyric journal, which is one of the independent sources of Turkish music, can be seen in line with the sources determined to be written since the 15th century. It is evident that all of the words that are studied from past to present have different results. The main reason for these different results is that every century, which is the aim of our study, has a different musical taste and culture. As a result, only lyric maqam, procedural and composer names are present in the journal, and there is no different information mentioned in the study. 11 maqams were used in the results related to the authorities, but the title of the yegah maqam was left blank despite being recorded. The maqam with the highest number of masters was 55 maqam and hicaz maqam. The maqams in the journal have been described by us as the favorite maqams of the period. The results of the rhythms include 14 different rhythms, while the most lyrical rhythm works are included, while at least 3 works with semia rhythms are included. In the results related to music forms, it was determined that besides 281 song forms, forms such as composition, walk-in, gazel were also included. Hac1 Arif Bey (30 compositions) followed Şevki Bey (37 compositions) whose most compositions were recorded in the journal. For the date of writing the lyric in the Tokat Mevlevihane Museum, the inventory record book was recorded in 1845 . However, considering Şevki Bey's date of birth (1860), it is seen that this date is not possible. While the date of 1845 is deducted, it is believed that h.25 April 1331, which is located inside, has been overlooked. It is known that there are many lyrical journalists in the libraries in the country and abroad who want to convey the musical culture of their time. It is important to reach these journals with a systematic study and reach their territory. Many of the lyrical journals available in many libraries face some physical problems such as ink leaks due to moisture, mold, wear and insect bites, and paper conservation is required because they are not well maintained. It is obvious that with the repair of these works, both the repertoire and theoretical contribution will be made to the rich culture of Turkish music.

Keywords: Musicology, Turkish music, 20th century, Lyrics Journal, Lyrics, Composition.

Öz: Güfte mecmuaları geçmişi geleceğe taşıyan, ait olduğu yüzyılın köklü ve kadim mûsikî kültürünü gelecek nesillere aktaran ve Tarihsel Müzikoloji alanı için tarihî belge özelliğine sahip kültür hazineleridir. Güfte mecmuaları, edvar kitapları içerisinde yer alan düz anlatımlı mûsikî formlarının bir nevî hayat bulup ve şekillendiği kaynaklardır. 15. yüzyıldan itibaren çok sayıda güfte mecmuası kaleme alınmıştır. Kaleme alınan bu eserlerin birçoğu günümüz Türkçesi ile akademik alana katkı sağlarken kütüphanelerin tozlu raflarında çalışılmayı bekleyen daha pek çok güfte mecmuasının var olduğu da bilinmektedir. Tokat Mevlevîhâne Müzesinde 60-0052 envanter kayıtlı, kim tarafından yazıldığı belli olmayan mecmuanın kaleme alınış yılı h.

Turkish Studies - Social, X(X) 
25 Nisan 1331 m. 8 Mayıs 1915'dir. Rika hattı ile kaleme alınan mecmuada yer alan eserlerin tamamı Türkçedir. Beste, yürük semâî, ağır semâî, gazel, şarkı gibi mûsikî formlarının, hicaz, kürdîlihicazkâr, sûzinak gibi makamların ve hafif, çenber, aksak, düyek gibi usûllerin yer aldığı mecmuada tamamı Türkçe toplam 307 eser bulunmaktadır. Yazılmış olduğu dönemin mûsikî kültürünün ortaya konmasının amaçlandığı çalışmada mecmua içerisinde yer alan besteler Türkiye Radyo ve Televizyon Kurumu (TRT) Arşivine göre numaralandırılmıştır. Mecmua içerisinde yer alan bazı bestelerin TRT Arşiv kaydına rastlanılmamış̧ır. Mecmua içerisinde yer alan güftelerde latinize yöntemi uygulanmış olup tespit edilen usûl, makam, form, bestekâr isimleri başlıklandırılmış ve bu başlıklar içerisinde yer alan diğer bulgular Sistematik Müzikoloji ihtiyaçları boyutunda alana faydalı hale getirilmeye çalışılmıştır.

Anahtar Kelimeler: Müzikoloji, Türk mûsikîsi, 20. yüzyıl, Güfte Mecmuası, Güfte, Beste.

\section{Giriş}

Güfte mecmuaları beste haline getirilmiş şiirlerin usûl, bestekâr ve makam bilgilerine göre cem edilmesi ile oluşan müstakil müzikoloji kaynaklarıdır. Güfte mecmualarının tarihsel seyri konusunda geriye dönüldüğünde 15 . yüzyıla kadar ulaştıkları görülmektedir. Tarihi belge niteliği taşıyan bu eserler yazılmış olduğu dönemin kadim ve zengin kültürel mirasının ve özellikle bestenin güfte değişimine uğrayıp uğramadığı gibi hususların ortaya konması bakımından büyük öneme sahiptirler. Edvar kitapları içerisinde yer alan mûsikî formlarına ait yapı özellikleri genellikle düz bir anlatımla sunulur ve nota örneklerine her edvar kitabı içerisinde rastlanmaz. Edvar kitapları içerisinde yer alan bu düz anlatımlar güfte mecmuaları içerisinde bir nevî hayat bulur ve şekillenir

Terminoloji bakımından terimler incelendiğinde mecmua, kelime anlamı olarak " dağınık şeyleri bir araya getirmek, toplamak" anlamındadır (Uzun, Mecmua, 2003: 265). İsm-i mef'ul olan ve Farsça goften mastarından gelen kelime "söylemiş" manasındadır (Öztuna, 2000: 37). Kâzım Uz güfte kelimesini Musiki Istılâhatı isimli eserinde "bestelenmiş nazım” olarak değerlendirmiştir (Uz, 1967: 28). Güfte mecmualarından farklı olarak ilâhi mecmuaları, gazel mecmuaları, beste mecmuaları gibi farklı mecmua türleri de mevcuttur (Soysal \& Aslan, 2014: 28).

Geçmişte meşk sistemi ile verilen Türk mûsikîsi repertuvar eğitiminde icra edilen eserlerin unutulmaması ve hafizaya destek olması için kaleme alınan güfte mecmuaları, XIX. yüzyıldan itibaren tamamı olmasa da bir kısmı bazı bestekârların kendi eserlerini tanıtmaya yönelik olarak ortaya koymuş oldukları bir çalışma haline gelmeye başlamıştır (Behar, 2006: 39).

Türk mûsikîsi için önemli birer kaynak olan güfte mecmuaları, içerisinde yalnızca güfteleri barındıran eserler değildirler. Hazine niteliğine sahip mecmualara ait eser yapraklarında nazarî bilgi niteliğine sahip birçok önemli noktaya ulaş1labilir (Uslu, 2001: 159).

Genellikle rika, talik, nesih gibi hatların kullanıldığı güfte mecmuaları ilk yazıldıkları dönemlerde el ile kaleme alınırken, matbaanın kullanımından sonra matbu olarak basılmaya başlanmıştır. Ancak matbaanın kullanılması ile el yazma mecmuaların artık yazılmadığı düşüncesinin gerçeği yansıtmayan bir düşünce şekli olduğu kabul edilmelidir. En eski yazma güfte mecmuası II. Murad zamanında kaleme alınmış güfte mecmuasıdır (Uslu, 2001: 159). Basılı olan ilk güfte mecmuası da Karamanlıca olarak 1830 yılında kaleme alınan Evterpi güfte mecmuasıdır (Behar, 2006: 39).

Güfte mecmuaları içerik açısından bazı farkl11ıklar gösterebilmektedirler. Bu farklılıkların temel sebeplerinin başında ise yazılmış olduğu yüzyıla göre değişen mûsikî zevki gelmektedir. Özellikle Türk mûsikîsindeki batı etkisi, Türk mûsikîsi ve saray, halkın mûsikî talebi gibi unsurlar bu değişimlerin oluşmasında temel etkenler olarak düşünülmektedir. Geçmişten günümüze bakıldığında ise yine bu değişimlerin birçoğunun özellikle form ve usûl açısından olduğu tespit edilmiştir. Örneğin 16. Yüzyılda Kâtîbî tarafından kaleme alınmış olduğu düşünülen ve Oxford Üniversitesi Bodleian Kütüphanesi 127-128 numaralı güfte mecmuasında (Parmaksız, 2016: 153, 
175, 177, 180) yer alan eserler ve usûller incelendiğinde dönemin mûsikî kültürünü yansitan amel, küll-î külliyât, muvaşşah, nevbet-i müretteb gibi eserler yanında çardarp, sakil, darbeyn, hâvî, mieteyn gibi usûller dikkati çekmektedir. Daha önce belirtilmiş olan batı etkisi ve diğer etkenler yüzyıllar içerisinde mûsikî kültürüne yönelik bir değişim süreci hazırlamakta, 19. yüzyıl sonundan itibaren bazı nazariyatçılar tarafından küçük usûller olarak değerlendirilen aksak, düyek, curcuna gibi usûller ile özellikle şarkı formunun ön planda olduğu eserlerin mecmualar içerisinde yer aldığı görülmektedir.

Güfte mecmuası literatürüne bakıldığında kitap, tez, bildiri ve makale gibi birçok akademik çalışmaya ulaşılabilir. Kitap olarak sunulmuş bazı çalışmalar şöyledir:

- Derviş Avni Güfte ve Şiir Mecmuasl ${ }^{1}$

- $\quad$ XV. Yüzyllda Bir Mecmua-i Güfte

- Fatih Sultan Mehmed Döneminde Musiki- Şems-i Rumi'nin Mecmua-i Güfte'si

- Derviş Mehmed El-Mevlevi'ye Ait Güfte Mecmuası (Mirac ve Ayin Mecmuası) ${ }^{4}$

Tez olarak sunulmuş bazı çalışmalar şöyledir:

- Hafız Post Güfte Mecmuası Türkçe Güfteler ${ }^{5}$

- XVIII. Yüzyıla Ait Bir Elyazması Mecmuada Dînî Mûsıkî Güfteleri ${ }^{6}$

- Müstakimzâde'nin "Mecmua-i Illâhiyât" Adlı Güfte Mecmuası ${ }^{7}$

- Hasan Gülşenî'nin Güfte Mecmuasi ve Incelenmesi ${ }^{8}$

- Bodlein Kütüphanesi 127-128 Numaralı Türk Musikisi Güfte Mecmuasinin Incelenmesi ${ }^{9}$

Makale ve bildiri olarak sunulmuş bazı çalışmalar şöyledir:

- 1774 Tarihli Hâfiz Abdülbâk̂̂’ye Ait Güfte Mecmuasinın İncelenmesi ${ }^{10}$

- Yazma Güfte Mecmualart ve Osmanlı Mûsıkîsi Tarihi Bakımından Ehemmiyeti ${ }^{11}$

- Osmanlı Dönemi Güfte Mecmuaları Üzerine Bir Değerlendirme ${ }^{12}$

- XVIIT. Yüzyıla Ait Bir Güfte Mecmuası Incelemesi ${ }^{13}$

15. yüzyıldan günümüze birçok güfte mecmuası kaleme alınmıştır. Güfte mecmuası adına bazı eserlerin incelemesi yapılmış olsa da daha pek çok mecmua çalışılmayı beklemektedir. Türk

\footnotetext{
${ }^{1}$ Mustafa Çıpan, Derviş Avni Güfte ve Şiir Mecmuası, T.C.Konya Valiliği İl Kültür Müdürlüğü Yayınları, Konya 2000.

${ }^{2}$ Recep Uslu, XV. Yüzyllda Bir Mecmua-i Güfte (Nuruosmaniye Ktp., nr. 3135) veyâ Sultan II. Murad Devri Müziğinin Bir Kaynağı (ekitap), Yazarın Kendi Çabaları ile Basılmıştır, İstanbul 2007.

${ }^{3}$ Recep Uslu, Fatih Sultan Mehmed Döneminde Musiki- Şems-i Rumi'nin Mecmua-i Güfte'si, İstanbul Fetih Cemiyeti Yayınları, İstanbul 2007.

${ }^{4}$ Fatih Koca, Derviş Mehmed El-Mevlevi'ye Ait Güfte Mecmuası, Mans Yayınları, Ankara 2017.

${ }^{5}$ Nilgün Doğrusöz, Hafiz Post Güfte Mecmuası Türkçe Güfteler, Yüksek Lisans Tezi, İstanbul Teknik Üniversitesi, Sosyal Bilimler Enstitüsü, İstanbul 1993.

${ }^{6}$ M. Emin Soydaş, XVIII. Yüzyıla Ait Bir Elyazması Mecmuada Dînî Mûsık̂̂ Güfteleri, Yüksek Lisans Tezi, Marmara Üniversitesi, Sosyal Bilimler Enstitüsü, İstanbul, 2001.

7 Şengül Sağman, Müstakimzâde’nin "Mecmua-i İlâhiyât”" Adlı Güfte Mecmuası, Yüksek Lisans Tezi, Marmara Üniversitesi, Sosyal Bilimler Enstitüsü, İstanbul 2001.

${ }^{8}$ Serçin Erden, Hasan Gülşenî’nin Güfte Mecmuası ve İncelenmesi, Yüksek Lisans Tezi, İstanbul Teknik Üniversitesi, Sosyal Bilimler Enstitüsü, İstanbul 2004.

${ }^{9}$ Mehmet Nuri Parmaksı, Bodlein Kütüphanesi 127- 128 Numaralı Türk Musikisi Güfte Mecmuasının İncelenmesi, Yayınlanmamış Doktora Tezi, Gazi Üniversitesi, Güzel Sanatlar Enstitüsü, Ankara 2016.

${ }^{10}$ Fikri Soysal- Mustafa Uğurlu Aslan, "1774 Tarihli Hâfız Abdülbâkî̀ye Ait Güfte Mecmuasının İncelenmesi”, Rast Müzikoloji Dergisi, C.II, Say1: 1, 2014, s.68-88.

${ }^{11}$ Harun Korkmaz, "Yazma Güfte Mecmualart ve Osmanlı Mûsıkîsi Tarihi Bakımından Ehemmiyeti”, XI. Milli Türkoloji Kongresi, İstanbul 2015, s.675-680.

12 Mustafa Çıpan, "Osmanl Dönemi Güfte Mecmuaları Üzerine Bir Değerlendirme”, Osmanlı Dünyasında Şiir Uluslararas1 Sempozyumu, İstanbul 1999.

${ }^{13}$ Erol Başara, Mehtap Erdoğan, Zeynep Yıldız, “XVII. Yüzyıla Ait Bir Güfte Mecmuası İncelenesi”, M.Ü. İlahiyat

Fakültesi Dergisi, say1: 38, İstanbul 2010, s. 137-172.
} 
mûsikîsine ait yazılı literatürün tamamına ulaşmadan Türk mûsikîsi tarihinin yazılması ve incelenmesi tamamlanmış sayılmaz. Yazılmış olduğu dönemin mûsikî kültürünün ortaya konulmasının amaçlandığı çalışmada, 20. Yüzyılda kaleme alınan güfte mecmuasının Türk mûsikîsi bakımından önemi ve bizlere sunacağı bilgiler nelerdir, içerisinde hangi usûller, makamlar, bestekârlar, mûsikî formları, nazarî bilgiler yer almaktadır? sorularına bulunacak cevaplar ile sonuca ulaşılmaya çalışılmıştır.

\section{Metodoloji}

Sistematik müzikoloji bilginin sınıflandırılarak, araştırmacının ilgi duyduğu alana en pratik biçimde ulaşmasını amaçlar.

Sistematik müzikoloji kuralları çerçevesinde usûl, makam, form gibi başlıklar halinde düzenlenerek sınıflandırılmış ve latinize yöntemi uygulanarak müzikoloji alana faydalı hale getirilmiştir. Tarihsel müzikoloji içerisine dâhil olan bu çalışmasında Recep Uslu'ya ait "Türk Müziği Eğitim Tarihinde Güfte Mecmuaları ve İnceleme Esasları Üzerine Tespitler" "14 isimli bildiride yer alan yöntemler esas alınmıştır. Çalışmada kullanılan diğer yöntemler ise şu şekildedir:

- Mecmua içerisinde yer alan eser sayısının fazla olması sebebi ile güftelerin yalnızca birinci mısraları verilmiş olup güfteye ait ilk mısralar mecmuada yazıldığı gibi aktarılmıştır.

- 307 adet güfte alfabetik sıra ile verilmiştir

- Bazı bestekâr isimlerinde farklılıkların mevcut olması sebebi ile doğru kimlik tespitine gidilmiş olup tablo içerisinde dipnot ile verilmiştir. Aynı durum makam, usûl ve form bulguları için de uygulanmıştır.

- Mecmuada yer almamasına karşın tespit edilebilen güftekâr isimleri alfabetik sıra ile verilmiş olup, mecmua içerisinde yer alan güfte sayıları parantez içerisinde gösterilmiştir.

- Mecmua içerisinde yer alan bestekâr isimleri alfabetik sıra ile verilmiş olup bestekârların eser içerisinde yer alan beste sayıları parantez içerisinde gösterilmiştir.

- Makam, usûl, bestekâr, form sayıları mecmuada yazıldığı gibi verilmiş olup (örneğin Hicaz faslı içerisinde farklı makamlı eser tespit edilmiş olsa da bu dipnotla belirtilmiş ancak sayım sırasında hicaz eser grubuna dâhil edilmiştir) mevcut farklılıklar dipnot olarak belirtilmiştir.

- Mecmuada yer almayan bestekâr, usûl ve eksik cümleler [ ] ile tamamlanmıştır.

- Bestelere ait form bilgileri ve arşiv numaraları TRT Nota Arşiv kayıtlarına göre düzenlenmiştir.

- Kürdîlihicazkâr ve hicazkâr makamlarının, aksak- ağır aksak- yürük aksak, düyek- ağır düyek, yürüksemâî- senginsemâî usûllerinin toplam sayıları bir arada verilmiştir.

- Bestekâr, usûl ismi yer alan ancak güftesi verilmeyen eserler liste dişı bırakılmıştır.

- Güftelerde yer alabilecek değişimler hususunda incelemeye gidilmemiştir.

\section{Nüshanın Tanıtımı}

Okunaklı olarak rika hattı ve siyah mürekkeb ile kaleme alınan mecmua 19x13 cm ölçülerindedir. Mecmuayı kimin kaleme aldığına dair müellif ismi yer almamaktadır. Yazılış tarihi olarak h. 25 Nisan 1331 (m. 8 Mayıs 1915) kaydı bulunmaktadır. 307 güfte krem renkli, aharlı kâğıt üzerinde kaydedilmiştir. Mecmuanın birçok sayfası eksik ve boştur. Bordo renkli meşin kaplama ile ciltlenmiştir. Süsleme olarak siyah renk kalem ile çizilen ferman kâğıdı modelini andıran çerçeve kullanılmıştır. Mecmuada yegâh faslı başlık olarak verilmiş ancak güfte yazımı yapılmamıştır.

\footnotetext{
${ }^{14}$ Recep Uslu, “Türk Müziği Eğitim Tarihinde Güfte Mecmuaları ve Inceleme Esasları Üzerine Tespitler”, Müzikte 2000 Sempozyumu, İstanbul 2001.
} 


\section{Güfte Mecmuasında Yer Alan Mûsikî Formları}

Ağırsemâî (2), beste (6), gazel (10), köçekçe (1), methiye (1), nazîre (1), şark1 (281), Rumeli türküsü (1), yürüksemâî (4).

Güfte mecmuası içerisinde ağırsemâî, gazel, köçekçe, methiye, nazîre, şarkı, Rumeli türküsü, yürüksemâî formlarından oluşan 307 adet kayıtlı eser yer almaktadır. Beste ve yürüksemâî formu içerisinde nakış beste ve nakış yürüksemâi eserler de mevcut bulunmaktadır. Kaleme alındığı yüzyılın mûsikî kültürünün yansıması olarak mecmuada en fazla formun şarkı formu olduğu ve gazel formu ile devam ettiği görülmektedir. Şarkı formunun önemli temsilcilerinin vermiş olduğu eserlerin birçoğu mecmua içerisinde görülmektedir. Klasik dönemim son temsilcilerinden olan ve Türk mûsikîsinin şaheserleri olarak nitelendirilen eserleri besteleyen Hammâmızâde İsmâil Dede Efendi, Zekâi Dede, Dellâlzâde İsmâil Efendi gibi isimlerin de çoğunlukla şarkı formlu eserleri ile mecmua içerisinde yer aldığı görülmektedir.

\section{Güfte Mecmuasında Yer Alan Bestekârlar}

Abdülhalim Ağa ${ }^{15}$ (1), Acemler (1), Ahmet Ârifî Bey (1), Ahmet Râsim Bey (2), Aleksan Efendi (2), Ali Rif’at Çağatay (1), Arap Sâlih Efendi (1), Asdik A ğa (7), Basmacı Abdi Efendi (1), Bolâhenk Nûri Bey (1), Civan Ağa ${ }^{16}$ (11), Danbeni Rizâ Bey (1), Dellalzâde İsmail Efendi (2), Enderûnî Ali Bey (2), Fâiz Bey (1), Giriftzen Âsım Bey ${ }^{17}$ (9), Hacı Ârif Bey (30), Hacı Fâik Bey (8), Hafız Efendi (1), Hâfız Mehmet Eşref Efendi (1), Hâfız Yusuf Efendi (2), Hammâmızâde İsmail Dede Efendi (10), Hâşim Bey (5), İsmet Ağa (1), Kânûnî Cemil Bey (1), Kânûnî Gâlip Efendi (1), Kapril Efendi (1), Kara İsmâil Ağa ${ }^{18}$ (1), Kemânî Rızâ Efendi (2), Kemânî Tatyos Efendi (9), Küçük Mehmet Ağa ${ }^{19}$ (2), Kırımlı Neşet Molla (1), Laedrî (24), Kemânî Sarı Onnik Efendii ${ }^{20}$ (2), Lâtif Ağa ${ }^{21}$ (1), Lavtacı Hıristo ${ }^{22}$ (10), Lem'i Atli ${ }^{23}$ (1), Leon Hanciyan ${ }^{24}$ (1), Mahmut Celâleddin Paşa ${ }^{25}$ (6), Medenî Aziz Bey (1), Misırlı İbrahim Efendi ${ }^{26}$ (2), Misak Ağa (1), Muallim İsmâil Hakk1 Bey (1), Neyzen Rizâ Bey ${ }^{27}$ (3) Nikoğos Ağa (8), Nûman Ağa (1), Ömer Lütfi Dede (1), Rahmi Bey (3), Rif'at Bey (14), Santûrî Ethem Bey (12), Selânikli Ahmet Efendi ${ }^{28}$ (12), Şâkir Ağa (2), Şekerci Cemil Bey $^{29}$ (10), Şerbetçi İbrahim Ağa (1), Şevki Bey (37), Şeyh Ethem Efendi (1), Tanbûrî Ali Efendi (7), Tanbûrî Büyük Osman Bey ${ }^{30}$ (1), Tevfik Bey (1), Ûdî Âfet Efendi (1), Ûdî Asım Bey ${ }^{31}$ (1) Ûdî Avram (1), Ûdî Sabri Bey (2), Ûdî Sâmi Bey (4), Yusuf Ziyâ Paşa (1), Zekâi Dede ${ }^{32}$ (3).

Güfte mecmuası içerisinde 65 bestekârın eseri yer almakla birlikte 24 adet lâedri eser mevcuttur. Mecmua içerisinde şarkı formunun önemli temsilcilerinden olan Hacı Ârif Bey ve Şevki Bey eser sayısı olarak ön planda olduğu dikkat çekerken, klasik dönem bestekârlarının klasik formlu eserleri de yer almaktadır.

\footnotetext{
${ }^{15}$ Güfte mecmuasında Hacı Ağa olarak geçmektedir.

${ }^{16}$ Güfte mecmuasında Civan Bey ve Civan Efendi olarak geçmektedir.

${ }^{17}$ Güfte mecmuasında Asım Bey ve Asım Efendi olarak geçmektedir.

${ }^{18}$ Güfte mecmuasında İsmail Efendi olarak geçmektedir.

${ }^{19}$ Güfte mecmuasinda Mehmet Ağa olarak geçmektedir.

${ }^{20}$ Güfte mecmuasında Kemânî Onnik Efendi olarak da geçmektedir.

${ }^{21}$ Güfte mecmuasında Latif Efendi olarak geçmektedir.

${ }^{22}$ Güfte mecmuasında Hristaki olarak da geçmektedir.

${ }^{23}$ Güfte mecmuasında Lem'î Bey olarak geçmektedir.

${ }^{24}$ Güfte mecmuasında Leon Efendi olarak geçmektedir.

${ }^{25}$ Güfte mecmuasında Merhum Mahmut Paşa ve Mahmut Paşa olarak geçmektedir.

${ }^{26}$ Güfte mecmuasında Ûdî İbrahim Ağa, İbrahim Ağa olarak geçmektedir.

${ }^{27}$ Güfte mecmuasında Rızâ Bey olarak geçmektedir.

${ }^{28}$ Güfte mecmuasında Ahmet Efendi ve Ûdî Ahmet Efendi olarak da geçmektedir.

${ }^{29}$ Güfte mecmuasında Hâfız Cemil Bey ve Hâfız Cemil Efendi olarak da geçmektedir.

${ }^{30}$ Güfte mecmuasında Osman Bey olarak geçmektedir.

31 Eserin TRT Nota Arşivinde kayıtlı olmaması sebebi ile bestekârın kim olduğu anlaşılamamıştır.

${ }^{32}$ Güfte mecmuasında Zekâi Efendi olarak geçmektedir.
} 


\section{Güfte Mecmuasında Yer Alan Usûller}

Aksak- ağıraksak- yürükaksak (136), aksaksemâî (2), curcuna (63), çenber (1), çiftesofyan (11), devr-ihindî (9), düyek- ağırdüyek (15), hafif (1), katakofti (3), semâî (5), sofyan (20), Türkaksağı (9), yürüksemâî- senginsemâî (22).

Mecmua içerisinde 13 adet farklı usûlün kullanıldığı bestelere yer verilmiştir. Müellif tarafından bestelere ait usûl isimleri aksak- ağır aksak- yürük aksak, düyek- ağır düyek olarak mertebeleri dikkate alınarak yazılmıştır. Bu bağlamda en fazla beste 136 adet ile aksak- ağır aksakyürük aksak usûlünde yer almaktadır. Yine dönemin mûsikî kültürünün yansıtılması bakımından güfte mecmuasından hareketle- en çok kullanılan usûllerden birinin de aksak usûlü ve mertebeleri olduğu belirlenmiştir. Bazan aksak usûlü için müellif tarafindan çifte sofyan usûlünün usûl ismi olarak kullanıldığı, semâî usûlü olarak yazılan usûlün de bazan yürüksemâî ve senginsemâîyi temsil ettiği tespit edilmiştir.

\section{Güfte Mecmuasında Yer Alan Makamlar}

Acemaşîran (5), bestenigâr (6), hicaz (55), hicazkâr- kürdîlihicazkâr (42), hüseynî (19), hüzzam (12), karcığar (15), nihâvend (18), rast (43), sûzinak (39), uşşak (43) makamlarına yer almaktadır.

Güfte mecmuası içerisinde en çok eserin yer aldığı makamın hicaz ve rast olduğu görülmektedir. Kullanılan bu makamların tıpkı formlarda ve usûllerde olduğu gibi dönemin gözde makamları olarak kabul edilmesinin de doğru bir tespit olduğu düşünülmektedir.

Ancak bazı makamlara ait bestelerin TRT Nota Arşivinde farklı makamlarda kayıtlı olduğu tespit edilmiştir. Gülizar makamlı bir eserin hüseynî, hicazkâr makamlı bir eserin sûzinak, uşşak makamlı eserin bayâti makamı içerisinde zikredilmesi gibi. Bu farklılığa genel olarak bakıldığında ise birbirlerine oldukça yakın makamlar olduğu dikkat çekmekle birlikte mecmuayı kaleme alan müellifin nazarî anlamda belirli bir bilgi birikimine sahip olduğu anlaşılmaktadır.

\section{Güfte Mecmuasında Güftesi Yer Alan Güftekârlar}

Abdülhamit Ziyâeddin Paşa ${ }^{33}$ (1), Ahmet Râsim Bey (8), Âkif Paşazâde Mustafa Reşit Bey (1), Ali Şefkatli Bey (1), Bâkî (1), Dede Efendi (2), Enderûnî Kemâlettin Ağa (1), Enderûnî Vâsif (2), Esad Paşazâde Said Bey (1), Fehîm-i Cedîd (1), Fitnat Hanım (1), Fuzûlî (3), Hacı Mustafa Nûri Bey (1), Hamdi Bey (1), Hasbî (2), Hüseyin Fâzıl Bey (1), İsmâil Münif (1), İsmâil Safâ Bey (1), Kara İsmâil Ağa (1), Keçecizâde İzzet Molla (2), Leylâ Saz (3), Mahfi Bey (1), Mahmut Celâleddin Paşa (4), Mâide Hanım (1), Mehmet Hâfid Bey (4), Mehmet Kâmil Çelebi (1), Mehmet Riyâzi Efendi (1), Mehmet Sâdi Bey (24), Mekkî Bey (2), Muallim Ahmet Feyzi Bey (1), Muallim Ömer Nâci Efendi (1), Mumduh Bey (1), Mustafa Reşit Bey (1), Nâbizâde Nâzım Bey (1), Nâmık Kemal (1), Nef'î (1), Nevres Efendi (1), Niğdeli Hikmet Bey (1), Recâizâde Mahmut Ekrem (5), Sabih Şevket Bey (1), Sabri Bey (1), Sâmih Rif’at Bey (1), Şekerci Cemil Efendi (1), Şemseddin Sivâsî (1), Şemsî (1), Şeyh Erhem Efendi (1), Şeyh Gâlip Dede (1), Tevfik Fikret (1), Üryânizâde Sait Efendi (1), Vezir Ziyâ Paşa (3), Yahya Kemal Beyatlı (1), Yenişehirli Hüseyin Avni Bey (1).

Bestelere ait güfte yazarlarının sadece 52 si tespit edilebilmiştir. M. Sâdi Bey 24 güfte ile en fazla güfteye sahiptir. Aynı zamanda Türk mûsikîsinin köşe taşları olarak nitelendirilen Dede Efendi, Enderûnî Vâsıf gibi bestekâr, Ziyâ Paşa, Fuzûlî, Yahya Kemal Beyatlı ve Tevfik Fikret gibi Türk edebiyatının önemli isimleri güftekârlar arasında yer almaktadırlar.

${ }^{33}$ Ziyâ Paşa. 
Tablo 1: Güfte Mecmuasında Yer Alan Eserlerin Alfabetik Sıralamas1

\begin{tabular}{|c|c|c|c|c|c|c|c|}
\hline & Eserin Adı & Bestekâr & Makam & Form & Usûl & $\begin{array}{l}\text { Sayfa } \\
\text { No }\end{array}$ & $\begin{array}{c}\text { TRT } \\
\text { Arşivi } \\
\text { No }\end{array}$ \\
\hline 1 & $\begin{array}{l}\text { Açdım yüzünü tal'at- } \\
1 \text { didârına bakdım }\end{array}$ & [Civan Ağa] & Rast $^{34}$ & Şark1 & Sofyan $^{35}$ & 25 & 65 \\
\hline 2 & $\begin{array}{l}\text { Adem oldukça rehâ } \\
\text { yok mu bana bu } \\
\text { sevdadan }\end{array}$ & - & - & Gazel & - & 373 & - \\
\hline 3 & $\begin{array}{l}\text { Ah felek yıktın dil-i } \\
\text { nâşâdımı }\end{array}$ & Leon Efendi & Hicaz & Şark1 & $\begin{array}{c}\text { Ağır } \\
\text { Aksak }\end{array}$ & 181 & 197 \\
\hline 4 & $\begin{array}{l}\text { Ah Yine neş'e-i } \\
\text { muhabbet dil ü } \\
\text { cânım etti şeydâ }\end{array}$ & Dede Efendi & Hicaz & Nakış & Semân̂ ${ }^{36}$ & 180 & 11484 \\
\hline 5 & $\begin{array}{l}\text { Ahter-i düşkün } \\
\text { garibi âşı-1 } \\
\text { âvâreyim }\end{array}$ & $\begin{array}{l}\text { Hacı Arif } \\
\text { Bey }\end{array}$ & Nihâvend & Şark1 & $\begin{array}{l}\text { Ağır } \\
\text { Aksak }\end{array}$ & 39 & 216 \\
\hline 6 & $\begin{array}{l}\text { Akşam olur güneş } \\
\text { gider șimdi buradan }\end{array}$ & Nikoğos Ăga & Hicazkâr & Şark1 & $\begin{array}{c}\text { Çifte } \\
\text { Sofyan } \\
\text { 37 }\end{array}$ & 113 & 292 \\
\hline 7 & $\begin{array}{l}\text { Ầlemde cânâ hicr ile } \\
\text { firkat benim olsun }\end{array}$ & Civan Ağa & Kürdîlihicazkâr & Şark1 & $\begin{array}{l}\text { Sengin } \\
\text { Semâî }\end{array}$ & 108 & 346 \\
\hline 8 & $\begin{array}{l}\text { Alınca gönlümü } \\
\text { mihr-i cemâli }\end{array}$ & $\begin{array}{l}\text { Hacı Arif } \\
\text { Bey }\end{array}$ & Sûzinak & Şark1 & Curcuna & 81 & 374 \\
\hline 9 & $\begin{array}{l}\text { Alıp aguşa o nazik } \\
\text { bedeni }^{38}\end{array}$ & - & Uşşak & Şark1 & Aksak & 137 & - \\
\hline 10 & $\begin{array}{c}\text { Aman ey gonca-i } \\
\text { nevres nihâlim }\end{array}$ & Rif'at Bey & Nihâvend & Şark1 & Curcuna $^{39}$ & 54 & 424 \\
\hline 11 & $\begin{array}{l}\text { Aman ey yâr-i cefâ- } \\
\text { pîșe nizâr etme beni }\end{array}$ & Riza Bey & Uşşak ${ }^{40}$ & Şark1 & Aksak & 133 & 430 \\
\hline 12 & $\begin{array}{l}\text { Anarım ismini } \\
\text { ağlarım, yanarım, } \\
\text { sızlanırım }^{41}\end{array}$ & Riza Bey & Nihâvend & Şark1 & Aksak & 42 & - \\
\hline 13 & $\begin{array}{l}\text { Andelîb-i sahn-1 aşka } \\
\text { gülşenim }\end{array}$ & $\begin{array}{l}\text { Dellâlzâde } \\
\text { İsmail Efendi }\end{array}$ & Rast & Şark1 & Düyek & 20 & 450 \\
\hline 14 & $\begin{array}{l}\text { Arz etsem acep } \\
\text { hâlimi ol sevgili yâre }\end{array}$ & $\begin{array}{l}\text { [Ömer Lütfi } \\
\text { Dede] }\end{array}$ & Rast & Şark1 & Aksak & 14 & 545 \\
\hline 15 & $\begin{array}{l}\text { Âş1k oldum sana ey } \\
\text { gonce dehen }\end{array}$ & Ali Efendi & Sûzinak & Şark1 & $\begin{array}{c}\text { Ağır } \\
\text { Aksak }\end{array}$ & 59 & 613 \\
\hline 16 & $\begin{array}{l}\text { Âşı oldur kim kılar } \\
\text { cânın fedâ cânânına }\end{array}$ & $\begin{array}{l}\text { Hacı Arif } \\
\text { Bey }\end{array}$ & Rast & Şark1 & Curcuna & 28 & 616 \\
\hline 17 & $\begin{array}{l}\text { Aşk ateşi sinemde } \\
\text { yine şûle feşandır }\end{array}$ & $\begin{array}{l}\text { Hacı Arif } \\
\text { Bey }\end{array}$ & Nihâvend & Şark1 & $\begin{array}{c}\text { Devr-i } \\
\text { Hindî }\end{array}$ & 49 & 639 \\
\hline 18 & $\begin{array}{c}\text { Aşka taş atmak } \\
\text { olmaz mübtela } \\
\text { neylesün }\end{array}$ & - & - & Gazel & - & 372 & - \\
\hline 19 & $\begin{array}{c}\text { Aşk-1 âhın halimde } \\
\text { diler }\end{array}$ & - & - & Gazel & - & 372 & - \\
\hline 20 & $\begin{array}{l}\text { Asskı pinhân edemem } \\
\text { nâle vü efgandır bu }\end{array}$ & $\begin{array}{l}\text { Hacı Arif } \\
\text { Bey }\end{array}$ & Karcığar & Şark1 & $\begin{array}{l}\text { Yürük } \\
\text { Sofyan }^{42}\end{array}$ & 295 & 769 \\
\hline
\end{tabular}

\footnotetext{
${ }^{34}$ Eser TRT Nota Arşivinde hüzzam makâmında kayıtlıdır.

${ }^{35}$ Eser TRT Nota Arşivinde curcuna olarak kayıtlıdır.

${ }^{36}$ Eser TRT Nota Arşivinde yürüksemâî olarak kayıtlıdır.

${ }^{37}$ Eser TRT Nota Arşivinde aksak olarak kayıtlıdır.

${ }^{38}$ TRT Nota Arşivinde kaydı bulunmamaktadır.

${ }^{39}$ Eser TRT Nota Arşivinde sofyan olarak kayıtlıdır.

${ }^{40}$ Eser TRT Nota Arşivinde bayâtî makâmında kayıtlıdır.

${ }^{41}$ Eser TRT Nota Arşivinde kayıtllı değildir.

${ }^{42}$ Eser TRT Nota Arşivinde düyek olarak kayıtlıdır.
} 


\begin{tabular}{|c|c|c|c|c|c|c|c|}
\hline 21 & $\begin{array}{l}\text { Aşkımı hûn narımı } \\
\text { mecnun eden }{ }^{43}\end{array}$ & $\begin{array}{c}\text { Hâfiz } \\
\text { Efendi }^{44}\end{array}$ & Kürdîlihicazkâr & Şark1 & Aksak & 97 & - \\
\hline 22 & $\begin{array}{l}\text { Aşkınla sînem } \\
\text { dağlarım }\end{array}$ & Nikoğos Ağa & Hicaz & Şarkı & Düyek & 200 & 743 \\
\hline 23 & $\begin{array}{l}\text { Ateş-i sûzân-1 firkat } \\
\text { yaktı cism ü cânımı }\end{array}$ & $\begin{array}{c}\text { Hacı Fâik } \\
\text { Bey }\end{array}$ & Hicaz & Şarkı & Curcuna & 216 & 828 \\
\hline 24 & $\begin{array}{c}\text { Atfetme sakın } \\
\text { hançer-i müjgânını } \\
\text { nâgâh }\end{array}$ & $\begin{array}{l}\text { Kemânî } \\
\text { Tatyos } \\
\text { Efendi }\end{array}$ & Sûzinak & Şark1 & $\begin{array}{l}\text { Sengin } \\
\text { Semâî }\end{array}$ & 74 & 838 \\
\hline 25 & $\begin{array}{l}\text { Azade ser iken of } \\
\text { ben şivekârım }\end{array}$ & $\begin{array}{l}\text { Ûdî Sabri } \\
\text { Bey }\end{array}$ & Hicaz & Şark1 & Aksak & 191 & - \\
\hline 26 & $\begin{array}{l}\text { Bağlanıp zülf-i } \\
\text { hezâran tâbına }\end{array}$ & Şevki Bey & Hicaz & Şark1 & $\begin{array}{l}\text { Devr-i } \\
\text { Hindî }\end{array}$ & 208 & 980 \\
\hline 27 & $\begin{array}{l}\text { Bahar geldi beyim } \\
\text { evde durulmaz }\end{array}$ & $\begin{array}{l}\text { [Şeyh Ethem } \\
\text { Efendi] }\end{array}$ & Hüzzam & Şark1 & Curcuna $^{46}$ & 273 & 1037 \\
\hline 28 & $\begin{array}{c}\text { Bak hâlime cânâ } \\
\text { bana çeşmim neler } \\
\text { etti }\end{array}$ & $\begin{array}{l}\text { Santûrî } \\
\text { Ethem } \\
\text { Efendi }\end{array}$ & Hüzzam & Şark1 & Aksak & 258 & - \\
\hline 29 & $\begin{array}{l}\text { Bak ne hâle koydu } \\
\text { bu baht-1 siyah }\end{array}$ & Rifat Bey ${ }^{47}$ & Hicaz & Şarkı & $\begin{array}{l}\text { Ağır } \\
\text { Aksak }\end{array}$ & 182 & 1140 \\
\hline 30 & $\begin{array}{l}\text { Bak neler varmış } \\
\text { kaderde bak neler }{ }^{48}\end{array}$ & Sâmi Bey & Uşşak & Şark1 & $\begin{array}{c}\text { Türk } \\
\text { aksağ1 }\end{array}$ & 137 & - \\
\hline 31 & $\begin{array}{l}\text { Bak şu güzel } \\
\text { köylüye işte bu } \\
\text { kızdır perî }\end{array}$ & Rızâ Bey & Hüseynî & Şark1 & Curcuna & 247 & 1144 \\
\hline 32 & $\begin{array}{l}\text { Bakmiyor çeşmi } \\
\text { siyah feryâde }\end{array}$ & $\begin{array}{c}\text { Hacı Arif } \\
\text { Bey }\end{array}$ & Nihâvend & Şark1 & $\begin{array}{c}\text { Çifte } \\
\text { Sofyan }^{49}\end{array}$ & 50 & 1136 \\
\hline 33 & $\begin{array}{l}\text { Bana doğru söyle } \\
\text { âhu-nigâhım }\end{array}$ & Ethem Bey ${ }^{50}$ & Hicaz $^{51}$ & Şark1 & Aksak & 192 & 1187 \\
\hline 34 & $\begin{array}{l}\text { Beni bîgâne mi } \\
\text { sandın a canım }\end{array}$ & $\begin{array}{l}\text { Arap Salih } \\
\text { Efendi }\end{array}$ & $\mathrm{Karc1ğar}^{52}$ & Şark1 & Curcuna & 297 & 1395 \\
\hline 35 & $\begin{array}{l}\text { Beni bîzâr ederken } \\
\text { serzenişler }\end{array}$ & $\begin{array}{l}\text { Hacı Arif } \\
\text { Bey }\end{array}$ & Sûzinak & Şark1 & Aksak & 68 & 1398 \\
\hline 36 & $\begin{array}{c}\text { Beni sevmez bilirim } \\
\text { de yine de sevsin } \\
\text { dilerim }^{53}\end{array}$ & - & - & Gazel & - & 373 & - \\
\hline 37 & $\begin{array}{l}\text { Benim hâlim } \\
\text { firâkınla yamandır }\end{array}$ & $\begin{array}{l}\text { Hacı Fâik } \\
\text { Bey }\end{array}$ & Hicaz & Şark1 & Curcuna & 217 & 1444 \\
\hline 38 & $\begin{array}{l}\text { Benim yârim } \\
\text { güzeller serveridir }\end{array}$ & $\begin{array}{l}\text { Tanbûri Ali } \\
\text { Efendi }\end{array}$ & Uşşak & Şark1 & Sofyan $^{54}$ & 150 & 1470 \\
\hline 39 & $\begin{array}{l}\text { Beyhûde değil nâle } \\
\text { vü âhım kederim var }\end{array}$ & Âsım Bey & Sûzinak ${ }^{55}$ & Şark1 & Aksak & 66 & 1571 \\
\hline 40 & $\begin{array}{c}\text { Biçak düşmez } \\
\text { belinden }\end{array}$ & Şevki Bey & Uşşak $^{56}$ & Şark1 & $\begin{array}{c}\text { Çifte } \\
\text { Sofyan }^{57}\end{array}$ & 148 & 1604 \\
\hline
\end{tabular}

\footnotetext{
43 TRT Nota Arşivinde kaydı bulunmamaktadır.

${ }^{44}$ Hâfız Efendi'ye ait eser TRT Nota Arşivinde kayıtlı olmaması sebebi ile Hâfız Efendi'nin kim olduğu tespit edilememiştir.

45 TRT Nota Arşivinde kaydı bulunmamaktadır.

${ }^{46}$ Eser TRT Nota Arşivinde Türkaksağı olarak kayıtlıdır.

${ }^{47}$ Eserin bestekârı TRT Nota Arşivinde Hacı Arif Bey olarak kayıtlıdır.

48 TRT Nota Arşivinde kaydı bulunmamaktadır.

${ }^{49}$ Eser TRT Nota Arşivinde aksak olarak kayıtlıdır.

${ }^{50}$ Eserin bestekârı TRT Nota Arşivinde Hacı Arif Bey olarak kayıtlıdır.

${ }^{51}$ Eser TRT Nota Arşivinde uşşak makâmında kayıtlıdır.

${ }^{52}$ Eser TRT Nota Arşivinde bayâti araban makâmında kayıtlıdır.

${ }^{53}$ Gazel, TRT Nota Arşivinde rast makâmında şarkı formunda kayıtlıdır.

${ }^{54}$ Eser TRT Nota Arşivinde aksak olarak kayıtlıdır.

${ }^{55}$ Eser TRT Nota Arşivinde hicazkâr makâmında kayıtlıdır.

${ }^{56}$ Eser TRT Nota Arşivinde muhayyer makâmında kayıtlıdır.

${ }^{57}$ Eser TRT Nota Arşivinde evfer olarak kayıtlıdır.
} 


\begin{tabular}{|c|c|c|c|c|c|c|c|}
\hline 41 & $\begin{array}{c}\text { Bîçâreyim ben } \\
\text { bîgâneyim ben }{ }^{58}\end{array}$ & - & Hicaz & Şark1 & $\begin{array}{l}\text { Sengin } \\
\text { Semâî }\end{array}$ & 204 & - \\
\hline 42 & $\begin{array}{l}\text { Bilmem kime şekvâ } \\
\text { edeyim derd-i } \\
\text { derûnum }\end{array}$ & Şevki Bey & Uşşak & Şark1 & $\mathrm{Aksak}^{59}$ & 138 & 1690 \\
\hline 43 & $\begin{array}{l}\text { Bilse bir kere o şuh } \\
\text { hâl-i perîşânımızı }\end{array}$ & $\begin{array}{l}\text { [Ahmet Arifî } \\
\text { Bey] }\end{array}$ & Rast & Şark1 & Aksak & 14 & 1726 \\
\hline 44 & $\begin{array}{l}\text { Bilseydim hâlimi } \\
\text { dostlar }\end{array}$ & - & Hicaz & Şark1 & Curcuna & 220 & - \\
\hline 45 & $\begin{array}{l}\text { Bin cân ile sevdim } \\
\text { seni }\end{array}$ & Osman Bey & Rast & Şark1 & Curcuna $^{60}$ & 30 & 1733 \\
\hline 46 & $\begin{array}{l}\text { Bir acâib hâb-1 } \\
\text { gaflete düştüm }\end{array}$ & Civan Ağa & Rast & Şark1 & Düyek & 20 & 1755 \\
\hline 47 & $\begin{array}{l}\text { Bir goncaya bir hâre } \\
\text { nigâh eyledi bülbül }\end{array}$ & $\begin{array}{c}\text { Hacı Arif } \\
\text { Bey }\end{array}$ & Karciğar & Şarkı & Semâ̂1 ${ }^{61}$ & 290 & 1931 \\
\hline 48 & $\begin{array}{l}\text { Bir gonce-dehen } \\
\text { üzdü beni hayli } \\
\text { zamandır }\end{array}$ & $\begin{array}{c}\text { Muallim } \\
\text { İsmail Hakkı } \\
\text { Bey }\end{array}$ & Hicaz & Şark1 & Aksak & 188 & 1933 \\
\hline 49 & $\begin{array}{c}\text { Bir görüş̧te ey perî } \\
\text { yandım sana }\end{array}$ & Kapril Efendi & Hüseynî & Şark1 & $\begin{array}{l}\text { Devr-i } \\
\text { Hindî }\end{array}$ & 240 & 1959 \\
\hline 50 & $\begin{array}{c}\text { Bir günah ettimse } \\
\text { câna sûznâk oldum } \\
\text { yeter }\end{array}$ & $\begin{array}{l}\text { Ahmet } \\
\text { Efendi }\end{array}$ & Sûzinak & Şark1 & $\begin{array}{l}\text { Ağır } \\
\text { Aksak }\end{array}$ & 62 & 1981 \\
\hline 51 & Bir güzele kul oldum & $\begin{array}{l}\text { Aleksan } \\
\text { Efendi }\end{array}$ & Sûzinak & Şark1 & $\begin{array}{c}\text { Çifte } \\
\text { Sofyan }\end{array}$ & 79 & 2039 \\
\hline 52 & $\begin{array}{l}\text { Bir katre içen çeşme- } \\
\text { i pür-hûn-i fenadan }\end{array}$ & Şevki Bey & Uşşak $^{63}$ & Şark1 & Aksak & 132 & 2102 \\
\hline 53 & $\begin{array}{l}\text { Bir kerre n'olur şuh-i } \\
\text { şenim hem tenim } \\
\text { olsan }\end{array}$ & $\begin{array}{l}\text { A. Râsim } \\
\text { Bey }\end{array}$ & Hicaz & Şark1 & Curcuna & 218 & 2110 \\
\hline 54 & $\begin{array}{c}\text { Bir melek-sîma } \\
\text { nâzenin }\end{array}$ & $\begin{array}{c}\text { [Şerbetçi } \\
\text { İbrâhim Ağa] }\end{array}$ & Sûzinak & Şark1 & Düyek & 72 & 2160 \\
\hline 55 & $\begin{array}{l}\text { Bir nigah et bana } \\
\text { çeşmânına hayran } \\
\text { olayım }\end{array}$ & $\begin{array}{l}\text { Ethem } \\
\text { Efendi }\end{array}$ & Uşşşak & Şark1 & Aksak & 130 & 2189 \\
\hline 56 & $\begin{array}{c}\text { Bir nigâh et ne olur } \\
\text { halime ey gonce } \\
\text { dehen }\end{array}$ & $\begin{array}{l}\text { Hafiz Cemil } \\
\text { Bey }\end{array}$ & Hicaz & Şark1 & Aksak & 189 & 2191 \\
\hline 57 & $\begin{array}{l}\text { Bir nigehle yaktın ey } \\
\text { mehveș teni }\end{array}$ & Misak Ağa & Nihâvend & Şark1 & $\begin{array}{l}\text { Sengin } \\
\text { Semâî }\end{array}$ & 47 & 2199 \\
\hline 58 & $\begin{array}{l}\text { Bir sevda geldi } \\
\text { başıma }\end{array}$ & Dede Efendi & Hicaz & Köçekçe & Curcuna $^{64}$ & 218 & 2250 \\
\hline 59 & $\begin{array}{l}\text { Bir yana eğdir fes'in } \\
\text { ey nev-civan }\end{array}$ & Nikoğos Ağa & Hüseynî & Şark1 & Aksak & 232 & 2332 \\
\hline 60 & $\begin{array}{c}\text { Bir zamanım yok ki } \\
\text { gönlümden kederler } \\
\text { eksile }^{65}\end{array}$ & $\begin{array}{c}\text { Kânûnî } \\
\text { Cemil Bey }\end{array}$ & Kürdîlihicazkâr & Şark1 & Aksak & 94 & - \\
\hline 61 & $\begin{array}{l}\text { Bîzâr ediyor âlemi } \\
\text { bu hâl-i tebâhım }\end{array}$ & Şevki Bey & Uşşak & Şark1 & Curcuna & 153 & 2413 \\
\hline 62 & $\begin{array}{c}\text { Bozuldu lânesi } \\
\text { üftâdegânın }\end{array}$ & - & Hicaz & Şark1 & Aksak & 194 & 2452 \\
\hline
\end{tabular}

\footnotetext{
${ }^{58}$ TRT Nota Arşivinde kaydı bulunmamaktadır.

${ }^{59}$ Eser TRT Nota Arşivinde aksak- Türkaksağı (değişmeli) olarak kayıtlıdır.

${ }^{60}$ Eser TRT Nota Arşivinde aksak olarak kayıtlıdır.

${ }^{61}$ Eser TRT Nota Arşivinde sengin semâî olarak kayıtlıdır.

${ }^{62}$ Eser TRT Nota Arşivinde sofyan olarak kayıtlıdır.

${ }^{63}$ Eser TRT Nota Arşivinde bayâtî makâmında kayıtlıdır.

${ }^{64}$ Eser TRT Nota Arşivinde aksak olarak kayıtlıdır.

${ }^{65}$ TRT Nota Arşivinde kaydı bulunmamaktadır.
} 


\begin{tabular}{|c|c|c|c|c|c|c|c|}
\hline 63 & $\begin{array}{l}\text { Bu akşam gün } \\
\text { batarken gel }\end{array}$ & $\begin{array}{l}\text { Kemânî } \\
\text { Tatyos } \\
\text { Efendi }\end{array}$ & Uşşak & Şark1 & Aksak & 136 & 2467 \\
\hline 64 & $\begin{array}{l}\text { Bu gönül ne gülde ne } \\
\text { gülşendedir }\end{array}$ & $\begin{array}{l}\text { Sarı Onnik } \\
\text { Efendi }\end{array}$ & Kürdîlihicazkâr & Şark1 & Aksak & 100 & 2499 \\
\hline 65 & $\begin{array}{l}\text { Bugün hâl-i firâk-1 } \\
\text { yar ile bîtâb-ü } \\
\text { giryânım }\end{array}$ & Tevfik Bey & Rast & Şark1 & Aksak & 10 & 2518 \\
\hline 66 & $\begin{array}{l}\text { Bülbül gibi pür oldu } \\
\text { cihân } \\
\text { nağmelerimden }\end{array}$ & Zekâi Dede & Hicazkâr & Şark1 & Semâ̂̂́ & 109 & 2653 \\
\hline 67 & $\begin{array}{l}\text { Câm-1 aşkın içtim } \\
\text { oldum derd-nâk }\end{array}$ & Şevkî Bey & Sûzinak & Şark1 & $\begin{array}{c}\text { A } \text { ğır } \\
\text { Aksak }\end{array}$ & 61 & 2704 \\
\hline 68 & $\begin{array}{c}\text { Cânâ rakîbi handân } \\
\text { edersin }\end{array}$ & Âsım Bey & Uşşak & Şark1 & Curcuna & 152 & 2733 \\
\hline 69 & $\begin{array}{c}\text { Canda cennetim mi } \\
\text { var sevda ihsanat } \\
\text { olmasa }\end{array}$ & $\begin{array}{l}\text { Hacı Faik } \\
\text { Bey }^{67}\end{array}$ & Uşşak ${ }^{68}$ & Şark1 & Sofyan & 170 & 2746 \\
\hline 70 & $\begin{array}{l}\text { Canım gibi sevdikçe } \\
\text { seni gönlüm ey âfet }\end{array}$ & Şevki Bey & Uşşak & Şark1 & Aksak & 131 & 2761 \\
\hline 71 & $\begin{array}{c}\text { Cemiyyet-i dil } \\
\text { koymadı mestâne } \\
\text { nigâhın }\end{array}$ & $\begin{array}{l}\text { Tanbûrî Ali } \\
\text { Efendi }\end{array}$ & Hicaz & Şark1 & $\begin{array}{l}\text { Sengin } \\
\text { Semâî }\end{array}$ & 203 & 2805 \\
\hline 72 & $\begin{array}{l}\text { Ciğerde nâr-1 hasret } \\
\text { açtı dağlar }\end{array}$ & Rifat Bey & Hicaz & Şark1 & $\begin{array}{l}\text { Ăgır } \\
\text { Düyek }\end{array}$ & 200 & 2829 \\
\hline 73 & $\begin{array}{c}\text { Cüdâ Düştü } \\
\text { Gözümden Gül- } \\
\text { izârın }\end{array}$ & Âsım Bey & Rast & Şark1 & Aksak & 12 & 2854 \\
\hline 74 & $\begin{array}{c}\text { Çamlıca ile } \\
\text { Kısıklı'nın arası }\end{array}$ & - & Karciğar & Şark1 & Curcuna & 298 & - \\
\hline 75 & $\begin{array}{l}\text { Çâre bulan olmadı } \\
\text { bu yâreye }\end{array}$ & $\begin{array}{l}\text { Ahmet } \\
\text { Râsim Bey }\end{array}$ & Hicaz & Şark1 & Curcuna & 217 & 2892 \\
\hline 76 & $\begin{array}{l}\text { Çekme elem-i } \\
\text { derdini bu dehri } \\
\text { fenanın }\end{array}$ & $\begin{array}{l}\text { Hacı Arif } \\
\text { Bey }\end{array}$ & Sûzinak & Şark1 & Aksak & 67 & 2925 \\
\hline 77 & $\begin{array}{l}\text { Çektim elimi gayri } \\
\text { bu dünyâ hevesinden }\end{array}$ & $\begin{array}{l}\text { Kemânî } \\
\text { Tatyos } \\
\text { Efendi }\end{array}$ & Hüseynî & Şark1 & Curcuna & 244 & 2946 \\
\hline 78 & $\begin{array}{l}\text { Çeşm-i âlem } \\
\text { görmemiştir sen gibi } \\
\text { bir şeydâ mâh }\end{array}$ & Ethem Bey & Rast & Şark1 & $\begin{array}{c}\text { Ağır } \\
\text { Aksak }\end{array}$ & 5 & - \\
\hline 79 & $\begin{array}{c}\text { Çeşm-i cellâdın bu } \\
\text { yaşta girdi artık } \\
\text { kanıma }\end{array}$ & $\begin{array}{l}\text { Udî Asım } \\
\text { Efendi }^{71}\end{array}$ & Sûzinak & Şark1 & 2968 & 60 & 2968 \\
\hline 80 & $\begin{array}{l}\text { Çeşm-i celladın ne } \\
\text { kanlar döktü } \\
\text { kağıthânede }\end{array}$ & $\begin{array}{c}\text { Kemânî } \\
\text { Tatyos } \\
\text { Efendi }\end{array}$ & Rast & Şark1 & $\begin{array}{l}\text { Ağır } \\
\text { Aksak }\end{array}$ & 6 & 2969 \\
\hline 81 & $\begin{array}{l}\text { Çeşm-i mahmûrun } \\
\text { sebeptir nâle vü } \\
\text { feryâdıma }\end{array}$ & Asdik Efendi & Hicaz & Şark1 & $\begin{array}{l}\text { Ağır } \\
\text { Aksak }\end{array}$ & 183 & 2972 \\
\hline 82 & $\begin{array}{l}\text { Çeşm-i mestin } \\
\text { hasretiyle cism ü } \\
\text { cânı dağlarım }\end{array}$ & Asdik Efendi & Kürdîlihicazkâr & Şark1 & Curcuna & 117 & 2976 \\
\hline
\end{tabular}

\footnotetext{
${ }^{66}$ Eser TRT Nota Arşivinde yürüksemâî olarak kayıtlıdır.

${ }^{67}$ Bestekâr TRT Nota Arşivinde Hacı Arif Bey olarak kayıtlıdır.

${ }^{68}$ Eser TRT Nota Arşivinde 1sfahan makâmında kayıtlıdır.

${ }^{69}$ TRT Nota Arşivinde kaydı bulunmamaktadır.

${ }^{70}$ Eser TRT Nota Arşivinde kayıtll değildir.

${ }^{71}$ Bestekâr TRT Nota Arşivinde Tatyos Efendi olarak kayıtlıdır.
} 


\begin{tabular}{|c|c|c|c|c|c|c|c|}
\hline 83 & $\begin{array}{c}\text { Dâden dem ezel } \\
\text { secdeber-i rûy-i âlem } \\
\text { râ }\end{array}$ & - & Rast & $\begin{array}{l}\text { Yürük } \\
\text { Semâî }\end{array}$ & Semâî ${ }^{72}$ & 3 & 3106 \\
\hline 84 & $\begin{array}{c}\text { Demem cânâ beni } \\
\text { yâd et }\end{array}$ & Şevki Bey & Hicaz & Şark1 & Curcuna & 216 & 3222 \\
\hline 85 & $\begin{array}{l}\text { Derd-i sevdâlarına } \\
\text { azade-i candır } \\
\text { bütün }\end{array}$ & - & Hicaz & Şark1 & $\begin{array}{l}\text { Türk } \\
\text { Aksağ } 1\end{array}$ & 191 & - \\
\hline 86 & $\begin{array}{l}\text { Derdimi arz etmeğe } \\
\text { ol şûha bir bulmadım }\end{array}$ & $\begin{array}{c}\text { Enderûnî Ali } \\
\text { Bey }\end{array}$ & Hicaz & Şark1 & $\begin{array}{l}\text { Sengin } \\
\text { Semâî }\end{array}$ & 205 & 3261 \\
\hline 87 & $\begin{array}{l}\text { Dil bir güzele } \\
\text { meyletti hele }\end{array}$ & Dede Efendi & Rast & Şark1 & $\begin{array}{l}\text { Sengin } \\
\text { Semâî }\end{array}$ & 22 & 3359 \\
\hline 88 & $\begin{array}{l}\text { Dil bülbülü sad zâr-1 } \\
\text { gülistân-1 cemâlin ah }\end{array}$ & $\begin{array}{l}\text { Giriftzen } \\
\text { Âsım Bey }\end{array}$ & Hüzzam & Şark1 & Aksak & 259 & 3363 \\
\hline 89 & $\begin{array}{l}\text { Dil seni sevmeyeni } \\
\text { sevmede lezzet mi } \\
\text { olur }\end{array}$ & Civan Ağa & Nihâvend & Şark1 & Semâî & 48 & 3448 \\
\hline 90 & $\begin{array}{c}\text { Dil yâresini } \\
\text { andıracak yâre } \\
\text { bulunmaz }\end{array}$ & Şevki Bey & Hicaz & Şark1 & Aksak & 187 & 3464 \\
\hline 91 & $\begin{array}{l}\text { Dilerse şâdkâm } \\
\text { olsun diler gönlüm } \\
\text { hazîn olsun }\end{array}$ & $\begin{array}{l}\text { Udi Ahmet } \\
\text { Efendi }\end{array}$ & Kürdîlihicazkâr & Şark1 & Aksak & 96 & 3391 \\
\hline 92 & $\begin{array}{l}\text { Dil-i bî-çâre senin } \\
\text { çün yanıyor }\end{array}$ & $\begin{array}{c}\text { Merhum } \\
\text { Mahmut Paşa }\end{array}$ & Uşşak $^{74}$ & Şark1 & $\begin{array}{l}\text { Devr-i } \\
\text { Hindî }\end{array}$ & 168 & 3418 \\
\hline 93 & $\begin{array}{c}\text { Diyelim sen yok iken } \\
\text { ağliyorum }\end{array}$ & $\begin{array}{l}\text { Selânikli } \\
\text { Ahmet } \\
\text { Efendi }\end{array}$ & Kürdîlihicazkâr & Şark1 & Curcuna & 116 & 3489 \\
\hline 94 & $\begin{array}{c}\text { Doktor ne için } \\
\text { nabzımı aldın ele } \\
\text { söyle }\end{array}$ & Şevki Bey & Hicaz & Şark1 & Aksak & 186 & 3507 \\
\hline 95 & $\begin{array}{l}\text { Dûçâr-1 hicr-i yâr } \\
\text { olalı dîdem ağlıyor }\end{array}$ & Şevki Bey & Uşşak & Şark1 & Sofyan $^{75}$ & 149 & 3559 \\
\hline 96 & $\begin{array}{l}\text { Düğünüm olmak için } \\
\text { verdiğim netice }\end{array}$ & Asdik Efendi & - & - & Sofyan & 113 & - \\
\hline 97 & $\begin{array}{c}\text { Düşeyim der iken } \\
\text { eyvâh vefalısına }\end{array}$ & Riza Bey & Hicaz & Şark1 & Aksak & 188 & 3681 \\
\hline 98 & $\begin{array}{c}\text { Düşme ey âş1k } \\
\text { hayâle yağma yok }\end{array}$ & $\begin{array}{l}\text { Hac1 Arif } \\
\text { Bey }\end{array}$ & Uşşak $^{77}$ & Şark1 & Sofyan $^{78}$ & 170 & 3685 \\
\hline 99 & $\begin{array}{l}\text { Edâlı bir yosma } \\
\text { kararım aldı }\end{array}$ & $\begin{array}{l}\text { Tanbûrî Ali } \\
\text { Efendi }\end{array}$ & Hüseynî & Şark1 & Curcuna & 245 & 3741 \\
\hline 100 & $\begin{array}{l}\text { Edemem kimseye } \\
\text { hâlim hikâyet }\end{array}$ & $\begin{array}{l}\text { Hac1 Arif } \\
\text { Bey }\end{array}$ & Sûzinak & Şark1 & Aksak & 68 & 3746 \\
\hline 101 & $\begin{array}{l}\text { Efem şimdi eller } \\
\text { sözüne kandı }\end{array}$ & $\begin{array}{c}\text { [Lavtac1 } \\
\text { Hristo] }\end{array}$ & Hicazkâr $^{79}$ & Şark1 & Aksak & 98 & 3756 \\
\hline 102 & $\begin{array}{l}\text { Ehl-i aşkın } \\
\text { neşvegâh1 kûşe-i } \\
\text { meyhânedir }\end{array}$ & $\begin{array}{l}\text { Kemânî } \\
\text { Tatyos } \\
\text { Efendi }\end{array}$ & Hicazkâr & Şark1 & $\begin{array}{c}\text { Ağır } \\
\text { Aksak }\end{array}$ & 92 & 3782 \\
\hline 103 & $\begin{array}{l}\text { Ehl-i dil isen kendine } \\
\text { zevk eyle cefâyı }\end{array}$ & $\begin{array}{c}\text { Hac1 Arif } \\
\text { Bey }\end{array}$ & Rast & Şark1 & $\begin{array}{c}\text { Devr-i } \\
\text { Hindî }\end{array}$ & 24 & 3785 \\
\hline
\end{tabular}

\footnotetext{
${ }^{72}$ Eser TRT Nota Arşivinde yürüksemâî olarak kayıtlıdır.

${ }^{73}$ TRT Nota Arşivinde aydı bulunmamaktadır.

${ }^{74}$ Eser TRT Nota Arşivinde 1sfahan makâmında kayıtlıdır.

${ }^{75}$ Eser TRT Nota Arşivinde aksak olarak kayıtlıdır.

76 TRT Nota Arşivinde kaydı bulunmamaktadır. Hicazkâr ve kürdîlihicazkâr makamında yer alan eserlerin birlikte verilmesi sebebi ile eserin makamı tespit edilememiştir.

${ }^{77}$ Eser TRT Nota Arşivinde 1sfahan makâmında kayıtlıdır.

${ }^{78}$ Eser TRT Nota Arşivinde müsemmen olarak kayıtlıdır.

${ }^{79}$ Eser TRT Nota Arşivinde tâhir makamı olarak kayıtlıdır.
} 


\begin{tabular}{|c|c|c|c|c|c|c|c|}
\hline 104 & $\begin{array}{c}\text { Eksilmez artar cevrin } \\
\text { a cânım }\end{array}$ & Mahmut Paşa & Sûzinak & Şark1 & $\begin{array}{c}\text { Yürük } \\
\text { Sofyan }^{80}\end{array}$ & 78 & 3792 \\
\hline 105 & $\begin{array}{l}\text { El benim'çün seni } \\
\text { sarmış biliyor }\end{array}$ & Şakir Ağa ${ }^{81}$ & Acem Aşîran ${ }^{82}$ & Şark1 & Aksak & 331 & 3793 \\
\hline 106 & $\begin{array}{l}\text { El erdirmek visâli } \\
\text { yâre pek güç }\end{array}$ & Civan Ağa & Kürdîlihicazkâr & Şark1 & Düyek & 105 & 3798 \\
\hline 107 & $\begin{array}{l}\text { El verir artık cefâ ey } \\
\text { dil-şikes[te }]^{83}\end{array}$ & Ethem Bey & Sûzinak & Şark1 & Katakofti & 84 & - \\
\hline 108 & $\begin{array}{l}\text { Elimdeyken senin } \\
\text { gül-penbe destin }\end{array}$ & Hristo Efendi & Karciğar & Şark1 & Curcuna & 297 & 3827 \\
\hline 109 & $\begin{array}{l}\text { Esir-i zülf-i dildâr } \\
\text { oldu gönlüm }\end{array}$ & - & Hicaz & Şark1 & Aksak & 193 & - \\
\hline 110 & $\begin{array}{l}\text { Esti nesîm-i nev- } \\
\text { bahar }\end{array}$ & $\begin{array}{l}\text { Hacı Arif } \\
\text { Bey }\end{array}$ & Rast & Şark1 & $\begin{array}{l}\text { Türk } \\
\text { Aksağ1 }\end{array}$ & 12 & 3938 \\
\hline 111 & $\begin{array}{c}\text { Eşk-i çeşmim } \\
\text { hasretinle çağliyor }\end{array}$ & Ethem Bey & Hüzzam & Şark1 & $\begin{array}{l}\text { Çifte } \\
\text { Sofyan }\end{array}$ & 269 & 3946 \\
\hline 112 & $\begin{array}{l}\text { Etmiyor hiç } \\
\text { merhamet cânan } \\
\text { benim efgânıma }\end{array}$ & $\begin{array}{l}\text { Ahmet } \\
\text { Efendi }\end{array}$ & Sûzinak & Şark1 & $\begin{array}{l}\text { Ağır } \\
\text { Aksak }\end{array}$ & 62 & 3958 \\
\hline 113 & $\begin{array}{l}\text { Ey câzib-i vicdan ne } \\
\text { yaman âfet-i cansin }\end{array}$ & Asdik Efendi & Uşşak & Şark1 & Aksak & 129 & 4038 \\
\hline 114 & $\begin{array}{l}\text { Ey çeşm-i âhû hicr } \\
\text { ile tenhâlara saldın } \\
\text { beni }\end{array}$ & Dede Efendi & Hicaz & Nakış & Düyek & 179 & 4046 \\
\hline 115 & $\begin{array}{l}\text { Ey dil hevesi vuslatı } \\
\text { canan sana düşmez }\end{array}$ & $\begin{array}{c}\text { Küçük } \\
\text { Mehmet Ağa }\end{array}$ & Sûzinak & $\begin{array}{c}\text { A ğır } \\
\text { Semâî }^{85}\end{array}$ & $\begin{array}{l}\text { [Yürük } \\
\text { Semâî] }\end{array}$ & 58 & 4055 \\
\hline 116 & $\begin{array}{l}\text { Ey dil ne oldun } \\
\text { feryâd edersin }\end{array}$ & Civan Ağa & Uşşak & Şarkı & Curcuna & 152 & 4058 \\
\hline 117 & $\begin{array}{l}\text { Ey felek bâri bırak ki } \\
\text { yanayım ağlayayım }\end{array}$ & Asdik Efendi & Karciğar & Şark1 & $\begin{array}{c}\text { Ağır } \\
\text { Aksak }\end{array}$ & 281 & 4075 \\
\hline 118 & $\begin{array}{l}\text { Ey gül ne aceb } \\
\text { silsile-i müşk-i terin } \\
\text { var }\end{array}$ & $\begin{array}{l}\text { [Yusuf Ziyâ } \\
\text { Paşa] }\end{array}$ & Rast $^{86}$ & $\begin{array}{l}\text { Yürük } \\
\text { Semâî }\end{array}$ & $\begin{array}{c}\text { Türk } \\
\text { Aksağ }^{87}\end{array}$ & 15 & 4124 \\
\hline 119 & Ey güli bağı edâ & Dede Efendi & Hüzzam & Şark1 & $\begin{array}{c}\text { Çifte } \\
\text { Sofyan }^{88}\end{array}$ & 269 & 4127 \\
\hline 120 & $\begin{array}{c}\text { Ey hevâî meşreb } \\
\text { oldun bâisi } \\
\text { berbâdımın }\end{array}$ & Şevki Bey & Hicaz & Şark1 & $\begin{array}{c}\text { Ağır } \\
\text { Aksak }\end{array}$ & 181 & 4152 \\
\hline 121 & $\begin{array}{c}\text { Ey keremkâr } \\
\text { merhamet bîçâre } \\
\text { gönlüm hastadır }\end{array}$ & - & Hicaz & Şark1 & Aksak & 190 & - \\
\hline 122 & $\begin{array}{l}\text { Ey melek-haslet } \\
\text { şehinşâh-1 vahîd }\end{array}$ & Hâşim Bey & Hicazkâr & Şark1 & $\begin{array}{c}\text { A } \breve{g} 1 r \\
\text { Aksak }^{90}\end{array}$ & 89 & 4186 \\
\hline 123 & $\begin{array}{c}\text { Ey melek-hûb hayâl- } \\
\text { i kemterî }\end{array}$ & Nikoğos Ağa & Hüzzam & Şark1 & $\begin{array}{c}\text { Ağır } \\
\text { Aksak }\end{array}$ & 255 & 4187 \\
\hline
\end{tabular}

\footnotetext{
${ }^{80}$ Çifte sofyan olarak ifade edilmek istendiği düşünülmektedir. Eser TRT Nota Arşivinde aksak olarak kaydedilmiş olsa da eser notasında çiftesofyan olarak kayıtlıdır.

${ }^{81}$ Beste TRT Nota Arşivinde Dede Efendi olarak kayıtlıdır.

${ }^{82}$ Eser TRT Nota Arşivinde ferahfezâ makâmında kayıtlıdır.

${ }^{83}$ TRT Nota Arşivinde kaydı bulunmamaktadır.

${ }^{84}$ TRT Nota Arşivinde kaydı bulunmamaktadır.

${ }^{85}$ Eser TRT Nota Arşivinde yürüksemâî formunda kayıtlıdır.

${ }^{86}$ Eser TRT Nota Arşivinde neveser makamında kayıtlıdır.

${ }^{87}$ Eser TRT Nota Arşivinde yürüksemâî olarak kayıtlıdır.

${ }^{88}$ Eser TRT Nota Arşivinde aksak usulü olarak kayıtlıdır.

${ }^{89}$ TRT Nota Arșivinde kaydı bulunmamaktadır.

${ }^{90}$ Eser TRT Nota Arşivinde ağır düyek olarak kayıtlıdır.
} 


\begin{tabular}{|c|c|c|c|c|c|c|c|}
\hline 124 & $\begin{array}{c}\text { Ey padişâh-1 } \\
\text { saltanat-ârâ-y1 } \\
\text { yegâne }\end{array}$ & Rif'at Bey & Rast & Methiye & Düyek ${ }^{91}$ & 21 & 4224 \\
\hline 125 & $\begin{array}{l}\text { Ey sabr-1 melalim } \\
\text { alıp eden beni } \\
\text { hayran }^{92}\end{array}$ & $\begin{array}{l}\text { Giriftzen } \\
\text { Âsım Bey }\end{array}$ & Uşşak & Şark1 & Aksak & 138 & - \\
\hline 126 & $\begin{array}{l}\text { Ey serd-i kadem bağ- } \\
1 \text { letafette fedanım }{ }^{93}\end{array}$ & $\begin{array}{l}\text { Udî Sâmi } \\
\text { Bey }\end{array}$ & Hüzzam & Şark1 & Aksak & 259 & - \\
\hline 127 & $\begin{array}{c}\text { Ey şehenş̧âh-1 ferîd-i } \\
\text { rûzigâr }\end{array}$ & Hâş̧im Bey ${ }^{94}$ & Hicazkâr & Şark1 & $\begin{array}{l}\text { A }{ }_{\text {ğır }} \\
\text { Aksak }\end{array}$ & 89 & 4284 \\
\hline 128 & $\begin{array}{l}\text { Eyle vuslünden } \\
\text { efendim behrüdâr }\end{array}$ & Rif'at Bey & Hicazkâr & Şark1 & Düyek & 104 & 4342 \\
\hline 129 & $\begin{array}{l}\text { Feryâd ediyor âşık-1 } \\
\text { hasret-zede her an }\end{array}$ & Rif'at Bey & Rast & Şark1 & Aksak & 11 & 4418 \\
\hline 130 & $\begin{array}{l}\text { Feyz-bahş-i can iken } \\
\text { âleme şirin sözlerin }\end{array}$ & Hristo Efendi & Karcığar & Şark1 & $\begin{array}{l}\text { Yürük } \\
\text { Sofyan }^{95}\end{array}$ & 294 & 4441 \\
\hline 131 & $\begin{array}{c}\text { Firâkınla zâlim harâb } \\
\text { oldu can }\end{array}$ & Şevki Bey & Hicaz & Şark1 & Aksak & 192 & 4471 \\
\hline 132 & $\begin{array}{l}\text { Firkat-i cânan ile } \\
\text { nâlân mı oldun ey } \\
\text { gönül }\end{array}$ & Civan Ağa & Hüseynî & Şark1 & Aksak & 233 & 4477 \\
\hline 133 & $\begin{array}{l}\text { Firkatine can } \\
\text { dayanmaz }\end{array}$ & $\begin{array}{l}\text { Hafiz Cemil } \\
\text { Efendi }\end{array}$ & Sûzinak & Şark1 & Curcuna & 80 & 4481 \\
\hline 134 & $\begin{array}{l}\text { Gâh ümîd-i vuslat } \\
\text { eylersin gönül }\end{array}$ & Şevki Bey & Uşşak & Şark1 & $\begin{array}{l}\text { A } \breve{g} 1 r \\
\text { Aksak }\end{array}$ & 126 & 4505 \\
\hline 135 & $\begin{array}{l}\text { Gâhi ki eder turrası } \\
\text { damânını çide }\end{array}$ & İsmail Ağa & Uşşak & $\begin{array}{l}\text { Yürük } \\
\text { Semâî }\end{array}$ & $\begin{array}{l}\text { Yürük } \\
\text { Semâî }\end{array}$ & 123 & 4503 \\
\hline 136 & $\begin{array}{l}\text { Gam-bikes vatanı } \\
\text { şâd edecek sensin } \\
\text { efendim }^{96}\end{array}$ & Şevki Bey & Uşşak & Şark1 & Aksak & 128 & - \\
\hline 137 & $\begin{array}{l}\text { Gamdan âzâde } \\
\text { heman dünyada bir } \\
\text { meyhânedir }\end{array}$ & Rif'at Bey & Rast & Şark1 & Curcuna & 29 & 4509 \\
\hline 138 & $\begin{array}{c}\text { Geçti zahm-1 tîr-i } \\
\text { hicrin tâ dil-i nâ- } \\
\text { şâdıma }\end{array}$ & $\begin{array}{l}\text { Hac1 Arif } \\
\text { Bey }\end{array}$ & Kürdîlihicazkâr & Şark1 & $\begin{array}{c}\text { A ğır } \\
\text { Aksak }^{97}\end{array}$ & 91 & 4645 \\
\hline 139 & $\begin{array}{l}\text { Gel beni vaslınla şâd } \\
\text { et kıl kerem }\end{array}$ & $\begin{array}{l}\text { Bolâhenk } \\
\text { Nûri Bey }\end{array}$ & Hüseynî & Şark1 & $\begin{array}{c}\text { Ağır } \\
\text { Aksak }\end{array}$ & 228 & 4666 \\
\hline 140 & $\begin{array}{l}\text { Gel elâ gözlüm } \\
\text { efendim yanıma }\end{array}$ & $\begin{array}{l}\text { Kemânî } \\
\text { Tatyos } \\
\text { Efendi }\end{array}$ & Sûzinak & Şark1 & Katakofti & 84 & 4714 \\
\hline 141 & $\begin{array}{l}\text { Geldi eyyâm-1 bahâr } \\
\text { oldu safâlar âşikâr }\end{array}$ & $\begin{array}{l}\text { Tanbûri Ali } \\
\text { Efendi }\end{array}$ & Rast & Şark1 & $\begin{array}{l}\text { Türk } \\
\text { Aksağı }\end{array}$ & 15 & 4697 \\
\hline 142 & $\begin{array}{l}\text { Gelin kızlar anamıza } \\
\text { soralım }\end{array}$ & $\begin{array}{c}\text { Hac1 Arif } \\
\text { Bey }^{98}\end{array}$ & Nihâvend & Şark1 ${ }^{99}$ & Curcuna $^{100}$ & 52 & 4776 \\
\hline 143 & $\begin{array}{l}\text { Gelince bezm-i } \\
\text { mestâne }\end{array}$ & $\begin{array}{c}{[\text { Kırımlı }} \\
\text { Neşet Molla] }\end{array}$ & Acem Aşiran ${ }^{101}$ & Şark1 & Aksak & 331 & 4764 \\
\hline
\end{tabular}

\footnotetext{
${ }^{91}$ Eser TRT Nota Arşivinde sofyan olarak kayıtlıdır.

92 TRT Nota Arşivinde kaydı bulunmamaktadır.

93 TRT Nota Arşivinde kaydı bulunmamaktadır.

${ }^{94}$ Eserin bestekârı TRT Nota Arşivinde Bağdasar olarak kayıtlıdır.

${ }^{95}$ Eser TRT Nota Arşivinde aksak olarak kayıtlıdır.

${ }^{96}$ TRT Nota Arşivinde kaydı bulunmamaktadır.

${ }^{97}$ Eser TRT Nota Arşivinde ağır aksak- Türkaksağı olarak kayıtlıdır.

${ }^{98}$ Bestekâr TRT Nota Arşivinde Hacı Fâik Bey olarak kayıtlıdır.

${ }^{99}$ Eser TRT Nota Arşivinde fantezi olarak kayitlıdır.

${ }^{100}$ Eser TRT Nota Arşivinde semâî-düyek-curcuna olarak kayıtlıdır.

${ }^{101}$ Eser TRT Nota Arşivinde hüzzam makâmında kayıtlıdır.
} 


\begin{tabular}{|c|c|c|c|c|c|c|c|}
\hline 144 & $\begin{array}{l}\text { Gelseydin meclise ey } \\
\text { rûh-1 revânım }\end{array}$ & Aziz Bey & Hicaz & Şark1 & $\begin{array}{l}\text { Sengin } \\
\text { Semâî }\end{array}$ & 205 & - \\
\hline 145 & $\begin{array}{c}\text { Gerçi kıyamam iki } \\
\text { gözüm uykuya } \\
\text { kansın }\end{array}$ & $\begin{array}{l}\text { Hacı Arif } \\
\text { Bey }\end{array}$ & Karciğar & Şark1 & Aksak & 284 & 4873 \\
\hline 146 & $\begin{array}{l}\text { Gidelim Göksu'ya } \\
\text { bir âlem-i âb } \\
\text { eyleyelim }\end{array}$ & $\begin{array}{l}\text { Hristâki } \\
\text { Efendi }\end{array}$ & Hicazkâr & Şark1 & Aksak & 96 & 4899 \\
\hline 147 & $\begin{array}{l}\text { Gönlüm yine bir } \\
\text { ateş-i hicrâne dolaştı }\end{array}$ & Ethem Bey & Nihâvend & Şark1 & Aksak & 41 & 5145 \\
\hline 148 & $\begin{array}{c}\text { Gönlümü aşk } \\
\text { sûzinak etti aman }\end{array}$ & Ethem Bey & Sûzinak & Şark1 & $\begin{array}{l}\text { Devr-i } \\
\text { Hindî }\end{array}$ & 76 & - \\
\hline 149 & $\begin{array}{l}\text { Gönül bağlandı yine } \\
\text { bir güzele }\end{array}$ & - & Kürdîlihicazkâr & Şark1 & Curcuna & 118 & 5166 \\
\hline 150 & $\begin{array}{l}\text { Gönül beni } \\
\text { usandırdın of }\end{array}$ & $\begin{array}{l}\text { Udî Ahmet } \\
\text { Efendi }\end{array}$ & Karciğar & Şark1 & Aksak & 285 & 5169 \\
\hline 151 & $\begin{array}{c}\text { Gönülde cay-gir } \\
\text { olmuş himem var }{ }^{104}\end{array}$ & Mehmet A ğa & Hicaz & Şark1 & Curcuna & 219 & - \\
\hline 152 & $\begin{array}{l}\text { Gönüller uğrusu bir } \\
\text { yâr-i bî-amânım var }\end{array}$ & $\begin{array}{l}\text { Dellâlzâde } \\
\text { İsmail } \\
\text { Efendi }^{105}\end{array}$ & Hüseynî & $\begin{array}{l}\text { Nakış } \\
\text { Semâî }\end{array}$ & $\begin{array}{l}\text { Yürük } \\
\text { Semâî }\end{array}$ & 227 & 5243 \\
\hline 153 & $\begin{array}{l}\text { Gördüğüm gün } \\
\text { rûyini ey mehlika }\end{array}$ & $\begin{array}{l}\text { Nikoğos } \\
\text { Efendi }\end{array}$ & Hüseynî & Şark1 & $\begin{array}{c}\text { A } \breve{g} 1 r \\
\text { Aksak }\end{array}$ & 229 & 5283 \\
\hline 154 & $\begin{array}{l}\text { Gördüğ̈üm yerde } \\
\text { seni büht ile ey } \\
\text { gonce dehen }\end{array}$ & $\begin{array}{l}\text { Udî Ahmet } \\
\text { Efendi }\end{array}$ & Sûzinak & Şark1 & Aksak & 65 & 5292 \\
\hline 155 & $\begin{array}{l}\text { Göreli gül yüzünü a } \\
\text { canım }\end{array}$ & Âsım Bey & Hicaz & Şark1 & Aksak & 195 & 5325 \\
\hline 156 & $\begin{array}{l}\text { Görmedim uysun } \\
\text { felek âmâlıma }\end{array}$ & $\begin{array}{l}\text { Udî Ahmet } \\
\text { Efendi }\end{array}$ & Hüzzam & Şark1 & $\begin{array}{l}\text { A Ăır } \\
\text { Aksak }\end{array}$ & 256 & 5334 \\
\hline 157 & $\begin{array}{c}\text { Görünce ben seni ey } \\
\text { mâh }\end{array}$ & $\begin{array}{l}\text { Selânikli } \\
\text { Ahmet } \\
\text { Efendi }\end{array}$ & Hüseynî ${ }^{106}$ & Şark1 & Curcuna & 246 & 5366 \\
\hline 158 & $\begin{array}{l}\text { Görünce gerdeninde } \\
\text { çifte hâli }\end{array}$ & Hristaki & Sûzinak & Şark1 & Sofyan ${ }^{107}$ & 78 & 5367 \\
\hline 159 & $\begin{array}{l}\text { Göstermedi bir gün } \\
\text { bana bu baht-1 } \\
\text { siyâhım }\end{array}$ & Mahmut Paşa & Uşşak & Şark1 & $\begin{array}{l}\text { Sengin } \\
\text { Semâî }\end{array}$ & 145 & 5396 \\
\hline 160 & $\begin{array}{c}\text { Gözümden ey peri } \\
\text { rûyim }\end{array}$ & Rif'at Bey & Rast & Şark1 & Curcuna $^{108}$ & 29 & 5502 \\
\hline 161 & $\begin{array}{l}\text { Gûş et beni feryâd-1 } \\
\text { semergâh1 } \\
\text { seversen }^{109}\end{array}$ & - & Rast & Şark1 & Aksak & 16 & - \\
\hline 162 & $\begin{array}{l}\text { Gül hazîn, sümbül } \\
\text { perîşan, bâğ-1 zârın } \\
\text { şevki yok }\end{array}$ & Rahmi Bey & Uşşak $^{110}$ & Şark1 & Aksak & 132 & 5631 \\
\hline 163 & $\begin{array}{l}\text { Gülşen-i hüsnüne } \\
\text { kimler varıyor }\end{array}$ & Rif'at Bey & Hicaz & Şark1 & Sofyan ${ }^{111}$ & 211 & 5716 \\
\hline
\end{tabular}

102 TRT Nota Arşivinde kaydı bulunmamaktadır.

${ }^{103}$ Eser TRT Nota Arşivinde kayıtlı değildir.

104 TRT Nota Arşivinde kaydı bulunmamaktadır.

105 Bestekârı TRT Nota Arşivinde Kara İsmail Ağa olarak kayıtlıdır.

${ }^{106}$ Eser TRT Nota Arşivinde karcığar makâmında kayıtlıdır.

${ }^{107}$ Eser TRT Nota Arşivinde aksak-curcuna olarak kayıtlıdır.

${ }^{108}$ Eser TRT Nota Arşivinde yürüksemâî olarak kayıtlıdır.

${ }^{109}$ Eser TRT Nota Arşivinde kayıtlı değildir.

${ }^{110}$ Eser TRT Nota Arşivinde bayâtî makâmında kayıtlıdır.

${ }^{111}$ Eser TRT Nota Arşivinde aksak olarak kayıtlıdır. 


\begin{tabular}{|c|c|c|c|c|c|c|c|}
\hline 164 & $\begin{array}{l}\text { Günden güne hâl } \\
\text { olmada aşkınla } \\
\text { diğger-gûn }\end{array}$ & Hristo Efendi & Uşşak & Şark1 & Semâî112 & 144 & 5768 \\
\hline 165 & $\begin{array}{l}\text { Hâb-gâh-1 yâre } \\
\text { girdim arz için } \\
\text { ahvâlimi }\end{array}$ & $\begin{array}{l}\text { [Giriftzen } \\
\text { Âsım Bey] }\end{array}$ & Rast & Şark1 & $\begin{array}{c}\text { Türk } \\
\text { Aksağg1 }^{113}\end{array}$ & 16 & 5897 \\
\hline 166 & $\begin{array}{c}\text { Hâl-i dilimi şerh } \\
\text { edemem kimseye } \\
\text { eyvâh }\end{array}$ & $\begin{array}{l}\text { Hafiz Cemil } \\
\text { Efendi }\end{array}$ & Sûzinak & Şark1 & Aksak $^{114}$ & 69 & 5929 \\
\hline 167 & $\begin{array}{l}\text { Harâb oldu yerim } \\
\text { yurdum otağım }\end{array}$ & Şevki Bey & Kürdîlihicazkâr & Şark1 & Sofyan $^{115}$ & 112 & 6000 \\
\hline 168 & $\begin{array}{l}\text { Hasret-i hicrinledir } \\
\text { bî-çâre dil }\end{array}$ & [Rif'at Bey] & Hicazkâr & Şark1 & $\begin{array}{l}\text { Ağır } \\
\text { Aksak }\end{array}$ & 90 & 6019 \\
\hline 169 & $\begin{array}{l}\text { Hasta-i zevk-i } \\
\text { visâlindir gönül } \\
\text { çoktan beri }\end{array}$ & Laedri ${ }^{116}$ & Hicazkâr & Şark1 & Aksak & 95 & 6077 \\
\hline 170 & $\begin{array}{l}\text { Hastasın zannım } \\
\text { vefâ mahzunusun }\end{array}$ & Şevki Bey & Uşşak & Şark1 & Curcuna & 153 & 6078 \\
\hline 171 & $\begin{array}{l}\text { Hay soyu çapkın } \\
\text { nedir bundaki naz }\end{array}$ & - & Rast & Şark1 & Curcuna & 27 & - \\
\hline 172 & $\begin{array}{l}\text { Hayalin görseydim } \\
\text { ey nev-nihâlim }{ }^{118}\end{array}$ & $\begin{array}{l}\text { Udî İbrahim } \\
\text { Ağa }\end{array}$ & Hüzzam & Şark1 & Aksak & 258 & - \\
\hline 173 & $\begin{array}{l}\text { Hayâtım şîvekârım } \\
\text { dilpesendim. }\end{array}$ & $\begin{array}{c}\text { Kemânî } \\
\text { Onnik Efendi }\end{array}$ & Hicazkâr & Şark1 & Aksak & 98 & 6152 \\
\hline 174 & $\begin{array}{l}\text { Hayli demdir } \\
\text { görmedim cânânımı }\end{array}$ & Asım Bey & Sûzinak & Şark1 & $\begin{array}{l}\text { Ağır } \\
\text { Aksak }\end{array}$ & 61 & 6162 \\
\hline 175 & $\begin{array}{l}\text { Hem kamer hem } \\
\text { zühre hem müşteri } \\
\text { der }\end{array}$ & Acemlerin & Rast & $\begin{array}{l}\text { Nakış } \\
\text { Beste }\end{array}$ & $\begin{array}{l}\text { Devr-i } \\
\text { Hindî }\end{array}$ & 3 & 6203 \\
\hline 176 & $\begin{array}{l}\text { Hem sevip hem } \\
\text { yakadan attın beni }\end{array}$ & Nikoğos Ağa & Acem Aşîran & Şark1 & Aksak & 330 & 6205 \\
\hline 177 & $\begin{array}{l}\text { Her dem sözüm } \\
\text { efsûs ile eyvâh } \\
\text { olacaktır }\end{array}$ & $\begin{array}{l}\text { Udî Sabri } \\
\text { Bey }\end{array}$ & Bestenigâr & Şark1 & $\begin{array}{l}\text { Sengin } \\
\text { Semâî }\end{array}$ & 314 & 6257 \\
\hline 178 & $\begin{array}{l}\text { Her derd içün sinede } \\
\text { bir yâresi olsun }\end{array}$ & & & Gazel & & 373 & \\
\hline 179 & $\begin{array}{c}\text { Her kimde vardır aşk } \\
\text { ibtilâsı }\end{array}$ & Civan Ağa & Kürdîlihicazkâr & Şark1 & Düyek & 105 & 6294 \\
\hline 180 & $\begin{array}{l}\text { Hevâ-yı aşk eser } \\
\text { serde }\end{array}$ & Şevki Bey & Uşşak & Şark1 & $\begin{array}{c}\text { Çifte } \\
\text { Sofyan }^{119}\end{array}$ & 148 & 6368 \\
\hline 181 & $\begin{array}{c}\text { Heyecanım } \\
\text { harekâtım şu } \\
\text { garibana nazar }\end{array}$ & - & Hüzzam & Şark1 & Aksak & 260 & - \\
\hline 182 & $\begin{array}{c}\text { Hicrân oku sînem } \\
\text { deler }\end{array}$ & Şevki Bey & Nihâvend ${ }^{120}$ & Şark1 & $\begin{array}{c}\text { Türk } \\
\text { Aksağı }\end{array}$ & 42 & 6402 \\
\hline 183 & $\begin{array}{c}\text { Hicrân oku sînem } \\
\text { deler }\end{array}$ & Şevki Bey & Nihâvend ${ }^{121}$ & Şark1 & $\begin{array}{l}\text { Türk } \\
\text { Aksağ } 1\end{array}$ & 233 & 6402 \\
\hline 184 & $\begin{array}{l}\text { Hüsnüne etvâr-1 } \\
\text { nâzik şan senin }\end{array}$ & Sâmi Bey ${ }^{122}$ & Karciğar & Şark1 & Aksak & 284 & 6528 \\
\hline
\end{tabular}

\footnotetext{
${ }^{112}$ Eser TRT Nota Arşivinde yürüksemâî olarak kayıtlıdır.

${ }^{113}$ Eser TRT Nota Arşivinde müsemmen olarak kayıtlıdır.

${ }^{114}$ Eser TRT Nota Arşivinde senginsemâî olarak kayıtlıdır.

${ }^{115}$ Eser TRT Nota Arşivinde aksak- curcuna olarak kayıtlıdır.

116 TRT Nota Arşivinde bestekâr Kadri Bey (Doktor) olarak belirtilmiștir.

${ }^{117}$ Eser TRT Nota Arşivinde kayıtlı değildir.

118 Bestekârı TRT Nota Arşivinde Lem'i Atlı olarak kayıtlıdır.

${ }^{119}$ Eser TRT Nota Arşivinde aksak olarak kayıtlıdır.

${ }^{120}$ Eser TRT Nota Arşivinde hüseynî makâmında kayıtlıdır.

${ }^{121}$ Eser TRT Nota Arşivinde hüseynî makâmında kayıtlıdır.

${ }^{122}$ Bestekârı TRT Nota Arşivinde Lem'i Atlı olarak kayıtlıdır.
} 


\begin{tabular}{|c|c|c|c|c|c|c|c|}
\hline 185 & $\begin{array}{l}\text { Hüznüm kederim } \\
\text { değil mi belli }\end{array}$ & $\begin{array}{l}\text { Udi Avram } \\
\text { Bey }\end{array}$ & Hicaz & Şark1 & Aksak & 190 & 6538 \\
\hline 186 & $\begin{array}{l}\text { İftirakınla ümidim } \\
\text { hüzn içinde } \\
\text { ağlıyor }^{123}\end{array}$ & - & Bestenigâr & Şark1 & Aksak & 309 & - \\
\hline 187 & $\begin{array}{l}\text { İnfialim tali'-i na- } \\
\text { sâzedir }\end{array}$ & Ethem Bey ${ }^{124}$ & Nihâvend & Şark1 & $\begin{array}{c}\text { Çifte } \\
\text { Sofyan }\end{array}$ & 50 & 6701 \\
\hline 188 & $\begin{array}{l}\text { İntizâr-1 makdemin } \\
\text { ey bî-aman }\end{array}$ & Hâşim Bey & Hüseynî1 ${ }^{126}$ & Şark1 & $\begin{array}{c}\text { Ağır } \\
\text { Aksak }\end{array}$ & 228 & 6711 \\
\hline 189 & $\begin{array}{l}\text { İstedin de gönlümü } \\
\text { verdim sana }\end{array}$ & $\begin{array}{l}\text { Hafiz Cemil } \\
\text { Efendi }\end{array}$ & Bestenigâr & Şark1 & Curcuna & 320 & 6735 \\
\hline 190 & $\begin{array}{l}\text { Jaleler saçsin nesim } \\
\text { gülzâra dönsün cûy-i } \\
\text { bâr }\end{array}$ & $\begin{array}{c}\text { Hacı Fâik } \\
\text { Bey }\end{array}$ & Rast & Şark1 & Aksak & 11 & 6799 \\
\hline 191 & $\begin{array}{l}\text { Kaçma didemden } \\
\text { aman ey gül tenim }\end{array}$ & Şevki Bey ${ }^{127}$ & Uşşak & Şark1 & Aksak & 131 & 6823 \\
\hline 192 & $\begin{array}{c}\text { Kaçma mecbûrundan } \\
\text { ey âhû-yi vahşi ülfet } \\
\text { et }\end{array}$ & Hâşim Bey & Bestenigâr & Şark1 & $\begin{array}{l}\text { Ağır } \\
\text { Aksak }\end{array}$ & 305 & 6824 \\
\hline 193 & $\begin{array}{l}\text { Kalb-i sevdâ-zedeler } \\
\text { âh ile dâim inler }\end{array}$ & $\begin{array}{l}\text { Selânikli } \\
\text { Ahmet } \\
\text { Efendi }\end{array}$ & Kürdîlihicazkâr & Şark1 & Aksak & 94 & 6873 \\
\hline 194 & $\begin{array}{l}\text { Kalmadı sabrım } \\
\text { hasrete cânâ }\end{array}$ & Şevki Bey & Nihâvend & Şarkı & $\begin{array}{l}\text { Sengin } \\
\text { Semâî }\end{array}$ & 47 & 6960 \\
\hline 195 & $\begin{array}{l}\text { Kâr etmedi zâlim } \\
\text { sana bu âh ü enînim }\end{array}$ & $\begin{array}{c}\text { Ali Rif'at } \\
\text { Bey }\end{array}$ & Sûzinak & Şark1 & $\begin{array}{l}\text { Sengin } \\
\text { Semâî }\end{array}$ & 74 & 7003 \\
\hline 196 & $\begin{array}{l}\text { Karşıyaka'da İzmir'in } \\
\text { gülü }\end{array}$ & Hristo Efendi & Kürdîlihicazkâr & Şark1 & Sofyan ${ }^{128}$ & 114 & 7060 \\
\hline 197 & $\begin{array}{l}\text { Of gönül düştü yine } \\
\text { gülzâr-1 zevke }\end{array}$ & $\begin{array}{l}\text { Kemânî } \\
\text { Tatyos } \\
\text { Efendi }\end{array}$ & Hüseynî & Şark1 & Curcuna & 244 & 5207 \\
\hline 198 & $\begin{array}{c}\text { Kemend-i zülfün } \\
\text { esîr-i zülf-i yâr } \\
\text { oldum }\end{array}$ & $\begin{array}{l}\text { Udî Afet } \\
\text { Efendi }\end{array}$ & Karciğar & Şark1 & Sofyan $^{129}$ & 294 & 7104 \\
\hline 199 & $\begin{array}{l}\text { Kim olur zor ile } \\
\text { maksûduna reh-yâb-1 } \\
\text { zafer }\end{array}$ & Zekâi Efendi & Uşşak & Şark1 & Aksak & 129 & 7222 \\
\hline 200 & $\begin{array}{l}\text { Kimi mestâne } \\
\text { mihriyâr ile gülşende } \\
\text { yatar }\end{array}$ & & & Gazel & & 372 & \\
\hline 201 & $\begin{array}{c}\text { Kimseler gelmez } \\
\text { senin feryâd-1 âteş- } \\
\text { bârına }\end{array}$ & Şevki Bey & Uşşak & Şark1 & Aksak & 135 & 7240 \\
\hline 202 & $\begin{array}{l}\text { Kucağımda } \\
\text { büyütürken nâ-gâh }\end{array}$ & Şevki Bey & Uşşak & Şark1 & Aksak & 135 & 7285 \\
\hline 203 & $\begin{array}{l}\text { Kurdu meclis âşıan } \\
\text { meyhânede }\end{array}$ & $\begin{array}{l}\text { Hac1 Arif } \\
\text { Bey }\end{array}$ & Hicaz & Şark1 & Sofyan & 211 & 7309 \\
\hline 204 & $\begin{array}{l}\text { Küşâde tâli'im hem } \\
\text { bahtım uygun }\end{array}$ & Şevki Bey & Hüzzam & Şark1 & Curcuna & 272 & 7353 \\
\hline 205 & $\begin{array}{l}\text { Layık mı sana bu dîli } \\
\text { sevdâzede yansin }\end{array}$ & $\begin{array}{l}\text { Hafiz Cemil } \\
\text { Efendi }\end{array}$ & Hicazkâr & Şark1 & $\begin{array}{l}\text { Sengin } \\
\text { Semâî }\end{array}$ & 108 & 7374 \\
\hline
\end{tabular}

123 TRT Nota Arşivinde kaydı bulunmamaktadır.

${ }^{124}$ Bestekâr TRT Nota Arşivinde Mekkî Bey olarak kayıtlıdır.

${ }^{125}$ Eser TRT Nota Arşivinde aksak olarak kayıtlıdır.

${ }^{126}$ Eser TRT Nota Arşivinde gülizar makâmında kayıtlıdır.

${ }^{127}$ Eserin bestekârı TRT Nota Arşivinde Şekerci Cemil Bey olarak kayıtlıdır.

${ }^{128}$ Eser TRT Nota Arșivinde evfer olarak kayıtlıdır.

${ }^{129}$ Eser TRT Nota Arşivinde düyek olarak kayıtlıdır. 


\begin{tabular}{|c|c|c|c|c|c|c|c|}
\hline 206 & $\begin{array}{l}\text { Lutfeyle tabib } \\
\text { dinleme kalbim } \\
\text { benim öyle }\end{array}$ & Şevki Bey & Uşşak & Şark1 & Aksak & 130 & 7417 \\
\hline 207 & $\begin{array}{l}\text { Mahmûr bakış1 âşıka } \\
\text { bin lûtfa bedeldir }\end{array}$ & $\begin{array}{c}\text { Mahmut } \\
\text { Paşa }^{130}\end{array}$ & Kürdîlihicazkâr & Şark1 & Aksak $^{131}$ & 99 & 7432 \\
\hline 208 & $\begin{array}{l}\text { Mahvoldu şevkim } \\
\text { ruhum pür-ahzan }\end{array}$ & Rahmi Bey & Kürdîlihicazkâr & Şark1 & Curcuna & 95 & 0 \\
\hline 209 & $\begin{array}{l}\text { Mahvoldu şevkim } \\
\text { ruhum pür-ahzan }\end{array}$ & Rahmi Bey & Kürdîlihicazkâr & Şark1 & Curcuna & 119 & 0 \\
\hline 210 & $\begin{array}{l}\text { Mecbur oldum ben } \\
\text { bir güle }\end{array}$ & Hâşim Bey & Bestenigâr & Şark1 & $\begin{array}{l}\text { Yürük } \\
\text { Aksak }\end{array}$ & 309 & 7515 \\
\hline 211 & $\begin{array}{l}\text { Meclis bezendi sun } \\
\text { bâde sâkî }\end{array}$ & $\begin{array}{l}\text { [Hac1 Arif } \\
\text { Bey] }\end{array}$ & Sûzinak & Şark1 & Curcuna $^{132}$ & 82 & 7517 \\
\hline 212 & $\begin{array}{l}\text { Mecnun gibi ben } \\
\text { dağlar gezerken }{ }^{133}\end{array}$ & - & Hicaz & Şark1 & Sofyan & 213 & - \\
\hline 213 & $\begin{array}{l}\text { Mest olup süzdün } \\
\text { diye çeşmânı }\end{array}$ & Hristo Efendi & Karciğar ${ }^{134}$ & Şark1 & Curcuna $^{135}$ & 298 & 7651 \\
\hline 214 & $\begin{array}{l}\text { Mest olup süzdün } \\
\text { diye mestânını }\end{array}$ & $\begin{array}{c}\text { Lavtacı } \\
\text { Hristo Efendi }\end{array}$ & Hicaz & Şark1 & Sofyan $^{136}$ & 210 & 7651 \\
\hline 215 & $\begin{array}{c}\text { Meyhâne mi bu } \\
\text { bezm-i tarab- hâne-i } \\
\text { cem mi? }\end{array}$ & $\begin{array}{c}\text { Hacı Arif } \\
\text { Bey }\end{array}$ & Uşşak & Şark1 & Aksak & 128 & 7687 \\
\hline 216 & $\begin{array}{l}\text { Meyl edip ağyâri } \\
\text { aldın yannna }\end{array}$ & $\begin{array}{l}\text { Kemânî Rızâ } \\
\text { Efendi }\end{array}$ & Hüzzam & Şark1 & $\begin{array}{l}\text { A } \breve{g} 1 \mathrm{r} \\
\text { Aksak }\end{array}$ & 255 & 7696 \\
\hline 217 & $\begin{array}{l}\text { Meyle teskin eyle } \\
\text { saki âh ateş zarımı }\end{array}$ & $\begin{array}{c}\text { Hacı Fâik } \\
\text { Bey }\end{array}$ & Hicaz & Şark1 & $\begin{array}{c}\text { Ağır } \\
\text { Aksak }\end{array}$ & 182 & 7701 \\
\hline 218 & $\begin{array}{c}\text { Meyleder bu hanki } \\
\text { kim görse ey gönlüm } \\
\text { seni }\end{array}$ & & & Gazel & & 373 & - \\
\hline 219 & $\begin{array}{l}\text { Meyler süzülsün } \\
\text { meydâne gelsin }\end{array}$ & $\begin{array}{l}\text { Hacı Arif } \\
\text { Bey }\end{array}$ & Nihâvend & Şark1 & Aksak & 41 & 7699 \\
\hline 220 & $\begin{array}{l}\text { Mihnet zedeyim } \\
\text { aşkınla mahrûm-1 } \\
\text { safâyım }{ }^{137}\end{array}$ & $\begin{array}{l}\text { İbrahim } \\
\text { Efendi }^{138}\end{array}$ & Nihâvend & Şark1 & Düyek & 45 & - \\
\hline 221 & $\begin{array}{c}\text { Mihr-i aşkın feyz-i } \\
\text { âb etti dil-i } \\
\text { nâşâdım1 }{ }^{139}\end{array}$ & - & Rast & Şark1 & $\begin{array}{l}\text { Devr-i } \\
\text { Hindî }\end{array}$ & 24 & - \\
\hline 222 & $\begin{array}{l}\text { Mir'at1 ele al da bak } \\
\text { Allah'1 seversen }\end{array}$ & Mahmut Paşa & Uşşak & Şark1 & $\begin{array}{l}\text { Sengin } \\
\text { Semâî }\end{array}$ & 144 & 7731 \\
\hline 223 & $\begin{array}{c}\text { Muntazır teşrifine } \\
\text { hazır kayık }\end{array}$ & $\begin{array}{l}\text { Hac1 Arif } \\
\text { Bey }\end{array}$ & Hicazkâr & Şark1 & Sofyan ${ }^{140}$ & 112 & 7753 \\
\hline
\end{tabular}

130 TRT Nota Arşivinde bestekâr Şekerci Cemil Bey olarak kayıtlıdır.

${ }^{131}$ Eser TRT Nota Arşivinde müsemmen olarak kayıtlıdır.

${ }^{132}$ Eser TRT Nota Arşivinde aksak olarak kayıtlıdır.

${ }^{133}$ Güfte; Hacı Arif Bey tarafından Muhayyer makamında ve Türkaksağı usûlünde, Hacı Faik Bey tarafından gülizar makamında aksak usûlünde, Sântûrî Ethem Bey tarafından sultânîsegâh makamında aksak usûlünde, Şevki Bey tarafından uşşak makamında ve aksak usûlünde bestelenmiştir. Ancak bestekârı belli olmamakla birlikte sofyan usûlünde olan bu besteye T RT Arşivinde rastlanılmamıştır.

${ }^{134}$ Eser TRT Nota Arşivinde hicaz makâmında kayıtlıdır.

${ }^{135}$ Eser TRT Nota Arşivinde düyek usûlü olarak kayıtlıdır.

${ }^{136}$ Eser TRT Nota Arşivinde düyek olarak kayıtlıdır.

${ }^{137}$ Eser TRT Nota Arşivinde kayıtlı değildir.

138 İbrahim Efendi'ye ait eser TRT Nota Arşivinde kayıtlı olmaması sebebi ile İbrahim Efendi'nin kim olduğu tespit edilememiștir ancak müellifin yine mecmua içerisinde Mısırlı İbrahim Ağa'yı Udî İbrahim Ağa olarak da kaydetmesi ve bestekârları bey, efendi gibi farklı hitap şekilleri ile kullanması sebebi ile İbrahim Efendi’nin Mısırlı İbrahim Ağa olabilme ihtimali yüksektir. Tarafımızdan Mısırlı İbrahim Ağa olarak değerlendirilmiştir.

${ }^{139}$ Eser TRT Nota Arşivinde kayıtlı değildir.

${ }^{140}$ Eser TRT Nota Arşivinde aksak olarak kayıtlıdır. 


\begin{tabular}{|c|c|c|c|c|c|c|c|}
\hline 224 & $\begin{array}{c}\text { Muntazır teşrifine } \\
\text { hazır kayık }\end{array}$ & $\begin{array}{l}\text { Hacı Arif } \\
\text { Bey }\end{array}$ & Hicazkâr & Şark1 & Sofyan $^{141}$ & 212 & 7753 \\
\hline 225 & $\begin{array}{c}\text { Mûy-i jülidem } \\
\text { olubdur serde ankâ } \\
\text { lânesi }\end{array}$ & Şakir Ağa & Rast & Şark1 & $\begin{array}{l}\text { Ağır } \\
\text { Aksak }\end{array}$ & 5 & 7767 \\
\hline 226 & $\begin{array}{l}\text { Müjgânlarının yâresi } \\
\text { isler ciğerimden }\end{array}$ & Rif'at Bey & Hicaz & Şark1 & Aksak & 187 & 7778 \\
\hline 227 & $\begin{array}{l}\text { Mümkün mü bulmak } \\
\text { bu gönlüm seni }\end{array}$ & $\begin{array}{c}\text { [Hacı Faik } \\
\text { Bey] }\end{array}$ & Hicaz $^{142}$ & Şark1 & Curcuna $^{143}$ & 220 & 7782 \\
\hline 228 & $\begin{array}{l}\text { Müsstâk-i cemâlin } \\
\text { gece gündüz dil-i } \\
\text { șeydâ }\end{array}$ & Dede Efendi & Sûzinak & Beste & Curcuna $^{144}$ & 57 & 7813 \\
\hline 229 & $\begin{array}{l}\text { Nabzım ele almakta } \\
\text { tabîb çâre ne söyle }\end{array}$ & Ethem Bey & Hicaz & Nazîre & Aksak & 186 & 7843 \\
\hline 230 & $\begin{array}{l}\text { Nâr-1 aşkınla senin } \\
\text { ey nevcivan }\end{array}$ & Rifat Bey & Nihâvend & Şark1 & $\begin{array}{l}\text { Ağır } \\
\text { Aksak }\end{array}$ & 39 & 7872 \\
\hline 231 & $\begin{array}{l}\text { Nasıl düştüm bu } \\
\text { sevdaya of }{ }^{145}\end{array}$ & - & Hicaz & Şark1 & Aksak & 193 & - \\
\hline 232 & $\begin{array}{l}\text { Nâ-ümîd-i aşka } \\
\text { doktor var mı tıbbın } \\
\text { çâresi }\end{array}$ & $\begin{array}{l}\text { Hafiz Cemil } \\
\text { Efendi }\end{array}$ & Uşşsak & Şark1 & Aksak & 134 & 7842 \\
\hline 233 & $\begin{array}{c}\text { Nazarımda yine âfâk } \\
\text { oluyor }\end{array}$ & - & - & Gazel & - & 372 & - \\
\hline 234 & $\begin{array}{c}\text { Ne için geçmez aceb } \\
\text { bir günüm âzâd-1 } \\
\text { elem }\end{array}$ & Şevki Bey & Uşşsak & Şark1 & Aksak & 133 & 8014 \\
\hline 235 & $\begin{array}{c}\text { Nedendir bilmezdim } \\
\text { asla }^{146}\end{array}$ & $\begin{array}{l}\text { Hacı Arif } \\
\text { Bey }\end{array}$ & Hüseynî & Şark1 & Curcuna & 245 & - \\
\hline 236 & $\begin{array}{l}\text { Nedir bu hâletin ey } \\
\text { meh-cemâlin }\end{array}$ & Şevki Bey & Hüseynî & Şark1 & Curcuna & 246 & 8159 \\
\hline 237 & $\begin{array}{c}\text { Nesin sen a güzel } \\
\text { nesin }\end{array}$ & Dede Efendi & Sûzinak & $\begin{array}{l}\text { Ağır } \\
\text { Semâî }\end{array}$ & $\begin{array}{l}\text { Aksak } \\
\text { Semâî }\end{array}$ & 57 & 8213 \\
\hline 238 & $\begin{array}{l}\text { Neş'eyâb etmekte } \\
\text { hüzn-i kalb-i nâ- } \\
\text { şâdım seni }\end{array}$ & $\begin{array}{l}\text { Hâfiz Yusuf } \\
\text { Efendi }\end{array}$ & Sûzinak & Şark1 & $\begin{array}{l}\text { Devr-i } \\
\text { Hindî }\end{array}$ & 76 & 8227 \\
\hline 239 & $\begin{array}{l}\text { Neyledi gör bana ol } \\
\text { mâh-1 mehi }\end{array}$ & $\begin{array}{l}\text { Hac1 Arif } \\
\text { Bey }\end{array}$ & Rast & Şark1 & Curcuna & 28 & 7823 \\
\hline 240 & $\begin{array}{l}\text { Nice bir hasret-i } \\
\text { cânâna tahammül } \\
\text { edeyim }\end{array}$ & $\begin{array}{l}\text { Tanbûri Ali } \\
\text { Efendi }\end{array}$ & Hüseynî & Şark1 & $\begin{array}{l}\text { Aksak } \\
\text { Semâî }\end{array}$ & 238 & 8294 \\
\hline 241 & $\begin{array}{l}\text { Nihansin dideden ey } \\
\text { mesti nâzım }\end{array}$ & $\begin{array}{c}\text { Hacı Fâik } \\
\text { Bey }\end{array}$ & Rast & Şark1 & Curcuna & 30 & 8340 \\
\hline 242 & $\begin{array}{l}\text { N'olsun bu kadar âh } \\
\text { ü figan ah gönül }\end{array}$ & $\begin{array}{l}\text { Enderûnî Ali } \\
\text { Bey }\end{array}$ & Hicaz & Şark1 & $\begin{array}{l}\text { Sengin } \\
\text { Semâî }\end{array}$ & 203 & 7838 \\
\hline 243 & $\begin{array}{l}\text { Of hançeri ebrûsu } \\
\text { saplandı dile }\end{array}$ & Asdik Efendi & Kürdîlihicazkâr & Şark1 & Curcuna & 117 & 5962 \\
\hline 244 & $\begin{array}{c}\text { Of! Mükedder } \\
\text { peyderpeyle şimdi }\end{array}$ & $\begin{array}{l}\text { Hacı Arif } \\
\text { Bey }\end{array}$ & Rast & Şark1 & $\begin{array}{c}\text { Çifte } \\
\text { Sofyan }^{147}\end{array}$ & 25 & 7779 \\
\hline 245 & $\begin{array}{l}\text { Olmada diller rubûde } \\
\text { gamze-i câdûsuna }\end{array}$ & Hacı A ğa & Hicaz & Beste & Hafîf & 179 & 8477 \\
\hline 246 & $\begin{array}{c}\text { Ölse de aşı onulmaz } \\
\text { yâresi }\end{array}$ & Şevki Bey & Uşşak & Şark1 & $\begin{array}{l}\text { A } \mathrm{g} 1 \mathrm{r} \\
\text { Aksak }\end{array}$ & 125 & 8583 \\
\hline
\end{tabular}

${ }^{141}$ Eser TRT Nota Arşivinde aksak olarak kayıtlıdır.

${ }^{142}$ Eser TRT Nota Arşivinde hüzzam makâmında kayıtlıdır.

${ }^{143}$ Eser TRT Nota Arşivinde aksak olarak kayıtlıdır.

${ }^{144}$ Eser TRT Nota Arşivinde darbeyn olarak kayıtlıdır.

145 TRT Nota Arşivinde kaydı bulunmamaktadır.

146 TRT Nota Arşivinde kaydı bulunmamaktadır.

${ }^{147}$ Eser TRT Nota Arşivinde aksak olarak kayıtlıdır. 


\begin{tabular}{|c|c|c|c|c|c|c|c|}
\hline 247 & $\begin{array}{l}\text { Pek arzu ider } \\
\text { görmeyi canım }\end{array}$ & Rifat Bey & Rast & Şark1 & Curcuna $^{148}$ & 32 & 8720 \\
\hline 248 & $\begin{array}{l}\text { Pek cüdâ düştüm } \\
\text { gülümden ah }\end{array}$ & $\begin{array}{l}\text { Udî Ahmet } \\
\text { Efendi }\end{array}$ & Hüseynî & Şark1 & Aksak & 232 & 8724 \\
\hline 249 & $\begin{array}{l}\text { Penbelikle imtizac } \\
\text { etmiş tenin }\end{array}$ & Lem'i Bey & Hicazkâr & Şarkı & $\begin{array}{c}\text { Ağır } \\
\text { Aksak }\end{array}$ & 91 & 8749 \\
\hline 250 & $\begin{array}{l}\text { Pencere açıldı Bilal } \\
\text { oğlan }\end{array}$ & - & Hicaz & $\begin{array}{l}\text { Rumeli } \\
\text { Türküsü }\end{array}$ & Curcuna $^{149}$ & 219 & 8750 \\
\hline 251 & $\begin{array}{l}\text { Rahmetmedin asla } \\
\text { bana }^{150}\end{array}$ & $\begin{array}{l}\text { Tatyos } \\
\text { Efendi }\end{array}$ & - & - & Curcuna & 118 & - \\
\hline 252 & $\begin{array}{l}\text { Rahm1 yok bir yâre } \\
\text { düşdüm yok çâresi }{ }^{151}\end{array}$ & & & Gazel & & 374 & 8813 \\
\hline 253 & $\begin{array}{l}\text { Reng-i ruhsârına } \\
\text { gülgün dediler }\end{array}$ & Şevki Bey & Uşşak & Şark1 & $\begin{array}{l}\text { A } \breve{g ı r} \\
\text { Aksak }\end{array}$ & 125 & 8851 \\
\hline 254 & $\begin{array}{l}\text { Riyâsız çeşm-i } \\
\text { ahuyu severdim }\end{array}$ & Civan Ağa & Hicazkâr & Şarkı & Düyek & 104 & 8867 \\
\hline 255 & Ruyundan at nikâbı & $\begin{array}{l}\text { Hacı Arif } \\
\text { Bey }\end{array}$ & Nihâvend & Şark1 & Curcuna $^{152}$ & 53 & 8925 \\
\hline 256 & $\begin{array}{l}\text { Saklayıp kalb-i } \\
\text { mükedderede seni }\end{array}$ & Rif'at Bey & Sûzinak & Şark1 & Aksak & 65 & 9113 \\
\hline 257 & $\begin{array}{l}\text { Samur kaşlım nâzik- } \\
\text { edâdır }\end{array}$ & Ali Efendi & Hicaz & Şark1 & Sofyan $^{153}$ & 210 & 9117 \\
\hline 258 & $\begin{array}{c}\text { Sanma dile bir } \\
\text { düziye gam gelir }\end{array}$ & - & Rast & Şark1 & Curcuna & 27 & - \\
\hline 259 & $\begin{array}{c}\text { Sen bu yerden gideli } \\
\text { ey saçı zer }\end{array}$ & Şevki Bey & Hicaz & Şark1 & Sofyan & 212 & 9329 \\
\hline 260 & $\begin{array}{l}\text { Sen de mi hâlâ esir-i } \\
\text { zülfiyâr olmakdasın }\end{array}$ & $\begin{array}{l}\text { Udî Sami } \\
\text { Bey }\end{array}$ & Uşşak & Şark1 & $\begin{array}{l}\text { A } \breve{g} ı r \\
\text { Aksak }\end{array}$ & 160 & 9344 \\
\hline 261 & $\begin{array}{c}\text { Seni bir tenhada } \\
\text { bulsam }\end{array}$ & İsmet Ağa & Nihâvend & Şark1 & Curcuna & 53 & 9577 \\
\hline 262 & $\begin{array}{c}\text { Senin aşkınla çâk } \\
\text { oldum }\end{array}$ & $\begin{array}{c}\text { Basmaci } \\
\text { Abdi Efendi }\end{array}$ & Rast & Şark1 & Aksak $^{155}$ & 10 & 9593 \\
\hline 263 & $\begin{array}{l}\text { Sensin ey mihrim bu } \\
\text { âlemde muhabbet } \\
\text { rehberi }\end{array}$ & $\begin{array}{l}\text { Hâfız Yusuf } \\
\text { Efendi }\end{array}$ & Karcı̆gar & Şark1 & $\begin{array}{l}\text { Ağır } \\
\text { Aksak }\end{array}$ & 281 & 9640 \\
\hline 264 & $\begin{array}{l}\text { Serde sevdâ dilde } \\
\text { gam sînemde } \\
\text { peykân-1 keder }\end{array}$ & Şevki Bey ${ }^{156}$ & Hüseynî & Şark1 & $\begin{array}{l}\text { Ağır } \\
\text { Aksak }\end{array}$ & 229 & 9694 \\
\hline 265 & $\begin{array}{l}\text { Ser-tâ- kadem ey } \\
\text { penbe ten }\end{array}$ & Âsım Efendi & Rast & Şark1 & Aksak & 13 & 9685 \\
\hline 266 & $\begin{array}{l}\text { Sevdayı canı sen gül } \\
\text { nâzenin teni }{ }^{157}\end{array}$ & - & Rast & Şark1 & $\begin{array}{l}\text { Ağır } \\
\text { Aksak }\end{array}$ & 7 & - \\
\hline 267 & $\begin{array}{l}\text { Sevdiğim âzâde-i } \\
\text { hicrânınım }\end{array}$ & $\begin{array}{l}\text { Hâfız Cemil } \\
\text { Efendi }\end{array}$ & Hicazkâr & Şark1 & $\begin{array}{c}\text { A ğır } \\
\text { Aksak }\end{array}$ & 90 & 9802 \\
\hline 268 & $\begin{array}{l}\text { Sevdiğim cemâlin } \\
\text { çünki göremem }\end{array}$ & $\begin{array}{l}\text { Mahmut } \\
\text { Celâleddin } \\
\text { Paşa }\end{array}$ & Hüseynî & Şark1 & Sofyan ${ }^{158}$ & 242 & 9808 \\
\hline
\end{tabular}

\footnotetext{
${ }^{148}$ Eser TRT Nota Arşivinde aksaksemâî olarak kayıtlıdır.

${ }^{149}$ Eser TRT Nota Arşivinde aksak olarak kayıtlıdır.

150 TRT Nota Arşivinde kaydı bulunmamaktadır. Hicazkâr ve kürdîlihicazkâr makamları bir arada verildiği için eserin makamı tespit edilememiştir.

${ }^{151}$ TRT Nota Arşivinde selmek makâmında ve devr-ihindî usûlünde kayıtlıdır.

152 Eser TRT Nota Arşivinde aksak olarak kayıtlıdır.

${ }^{153}$ Eser TRT Nota Arşivinde aksak olarak kayıtlıdır.

${ }^{154}$ Eser TRT Nota Arşivinde kayıtlı değildir.

155 Eser TRT Nota Arşivinde düyek olarak kayıtlıdır.

${ }^{156}$ Bestekârı TRT Nota Arşivinde Nikoğos Ağa olarak kayıtlıdır.

${ }^{157}$ Eser TRT Nota Arșivinde kayıtlı değildir.

${ }^{158}$ Eser TRT Nota Arşivinde aksak usulü olarak kayıtlıdır.
} 


\begin{tabular}{|c|c|c|c|c|c|c|c|}
\hline 269 & $\begin{array}{l}\text { Sevdiğim pek } \\
\text { yaramazdır } \\
\text { yaramaz }^{159}\end{array}$ & [Aleksan] & Sûzinak & Şark1 & Curcuna & 82 & - \\
\hline 270 & $\begin{array}{l}\text { Seyr-i gülşen edelim } \\
\text { ey şivekâr aman }\end{array}$ & Dede Efendi & Hicaz & Şark1 & $\begin{array}{l}\text { A ğır } \\
\text { Düyek }\end{array}$ & 201 & 10015 \\
\hline 271 & $\begin{array}{l}\text { Silâ-i firkatin câna } \\
\text { hayâle oldu gam- } \\
\text { fermât }\end{array}$ & Civan Bey & Rast & Şark1 & Curcuna & 32 & - \\
\hline 272 & $\begin{array}{l}\text { Sohbetimi gerçek } \\
\text { sandın vah zavallı } \\
\text { pek aldandın }\end{array}$ & Numan Ağa & Acem Aşîran & Şark1 & Aksak & 330 & 10082 \\
\hline 273 & $\begin{array}{c}\text { Sormayın âyâ ne } \\
\text { oldum }\end{array}$ & $\begin{array}{c}\text { Şevkî } \\
\text { Efendi }^{161}\end{array}$ & Rast & Şark1 & Aksak & 13 & 10151 \\
\hline 274 & $\begin{array}{l}\text { Söyle Allah aşkına } \\
\text { ey nev-civan }\end{array}$ & $\begin{array}{l}\text { Hâfız Cemil } \\
\text { Efendi }^{162}\end{array}$ & Kürdîlihicazkâr & Şark1 & Aksak & 97 & 10164 \\
\hline 275 & $\begin{array}{l}\text { Söyle n'ettim ben } \\
\text { sana zâlim felek }\end{array}$ & $\begin{array}{c}\text { Hacı Faik } \\
\text { Bey }\end{array}$ & Bestenigâr & Şark1 & Sofyan $^{163}$ & 318 & 10193 \\
\hline 276 & $\begin{array}{c}\text { Suzinak-i âteş-i } \\
\text { aşkım yetiş imdâda } \\
\text { gel }\end{array}$ & Nikoğos Ağa & Sûzinak & Şark1 & Aksak & 66 & 10304 \\
\hline 277 & $\begin{array}{l}\text { Suzinak-i fasl-1 aşk1 } \\
\text { söyleyim dinle yeter }\end{array}$ & $\begin{array}{l}\text { [Tatyos } \\
\text { Efendi] }\end{array}$ & Sûzinak & Şark1 & $\begin{array}{l}\text { A } \breve{g} 1 \mathrm{r} \\
\text { Aksak }\end{array}$ & 60 & 10305 \\
\hline 278 & $\begin{array}{l}\text { Şebabet gitti de } \\
\text { elden başımdan } \\
\text { gitmiyor sevda }\end{array}$ & $\begin{array}{c}\text { [Şekerci } \\
\text { Cemil Bey] }\end{array}$ & Rast & Şark1 & Curcuna & 31 & 10394 \\
\hline 279 & $\begin{array}{l}\text { Şevkinle hayâlinde } \\
\text { olur neşe bedîdâr }\end{array}$ & $\begin{array}{l}\text { Hristo } \\
\text { Efendi }\end{array}$ & Hicaz & Şark1 & $\begin{array}{l}\text { Sengin } \\
\text { Semâî }\end{array}$ & 204 & 10429 \\
\hline 280 & $\begin{array}{l}\text { Şule-i dildâre yaktı } \\
\text { âh gönlümü sada } \\
\text { ile }^{164}\end{array}$ & - & Sûzinak & Şark1 & Curcuna & 80 & - \\
\hline 281 & $\begin{array}{l}\text { Tâ ezelden âşık } \\
\text { oldum ey peri } \\
\text { söylemez misin? }{ }^{165}\end{array}$ & - & Sûzinak & Şark1 & Aksak & 69 & - \\
\hline 282 & $\begin{array}{c}\text { Târ-1 zülfün beni etti } \\
\text { meshûr }\end{array}$ & $\begin{array}{l}\text { Hâfız Cemil } \\
\text { Efendi }\end{array}$ & Hicazkâr & Şark1 & Aksak & 99 & 10600 \\
\hline 283 & $\begin{array}{l}\text { Te'lif edebilsem } \\
\text { feleği âh emelimle }\end{array}$ & Şevki Bey & Uşşak & Şark1 & Aksak & 136 & 10624 \\
\hline 284 & $\begin{array}{c}\text { Tepeden nasil iniyor } \\
\text { bakın }\end{array}$ & Şevki Bey ${ }^{166}$ & Uşşak $^{167}$ & Şark1 & $\begin{array}{c}\text { Çifte } \\
\text { Sofyan }{ }^{168}\end{array}$ & 149 & - \\
\hline 285 & $\begin{array}{l}\text { Tîr-i nigehin açtı } \\
\text { ciğergâhıma yâre }\end{array}$ & $\begin{array}{l}\text { Selânikli } \\
\text { Ahmet } \\
\text { Efendi }\end{array}$ & Kürdîlihicazkâr & Şark1 & Aksak & 100 & 10683 \\
\hline 286 & $\begin{array}{l}\text { Uslanmadı hâlâ } \\
\text { emeli bitmedi } \\
\text { gönlüm }\end{array}$ & $\begin{array}{l}\text { Hacı Arif } \\
\text { Bey }\end{array}$ & Sûzinak & Şark1 & Aksak & 67 & 10811 \\
\hline 287 & Üzme beni ey peri ${ }^{169}$ & Ethem Bey & Nihâvend & Şark1 & Curcuna & 52 & - \\
\hline
\end{tabular}

\footnotetext{
159 TRT Nota Arşivinde kaydı bulunmamaktadır.

${ }^{160}$ Eser TRT Nota Arşivinde kayıtlı değildir.

${ }^{161}$ Bestekâr, TRT Nota Arşivinde Civan Ağa olarak kayıtlıdır.

162 TRT Nota Arşivinde bestekâr Sarı Onnik olarak kayıtlıdır.

${ }^{163}$ Eser TRT Nota Arşivinde aksak usûlü olarak kayıtlıdır.

164 TRT Nota Arşivinde kaydı bulunmamaktadır.

${ }^{165}$ Eser TRT Nota Arşivinde kayıtlı değildir.

166 TRT Nota Arşivinde aynı sözlerle gerdâniye makamlı Arif Sâmi Toker bestesi kayıtlıdır. Eserin bestecisi olarak Şevki Bey ile birlikte Tığlızâde Enderûnî Mehmet Bey’in de ismi geçmektedir. Şevki Bey besteli eserin TRT Nota Arşivinde kaydı da bulunmamaktadır.

${ }^{167}$ Eser TRT Nota Arşivinde gerdâniye makâmında kayıtlıdır.

${ }^{168}$ Eser TRT Nota Arșivinde aksak olarak kayıtlıdır.

${ }^{169}$ Eser TRT Nota Arşivinde kayıtlı değildir.
} 


\begin{tabular}{|c|c|c|c|c|c|c|c|}
\hline 288 & $\begin{array}{l}\text { Va'd eylemiştin ey } \\
\text { perî }\end{array}$ & $\begin{array}{c}\text { Hafiz } \\
\text { Mehmet } \\
\text { Efendi }\end{array}$ & Sûzinak & Şark1 & Düyek & 72 & 10903 \\
\hline 289 & $\begin{array}{l}\text { Vakf-1 râhı aşkın } \\
\text { etmişken bütün cân ü } \\
\text { teni }\end{array}$ & Zekâî Efendi & Sûzinak & Şark1 & $\begin{array}{l}\text { Ağır } \\
\text { Aksak }\end{array}$ & 59 & 10917 \\
\hline 290 & $\begin{array}{l}\text { Varken gönülde bin } \\
\text { türlü yâre }\end{array}$ & $\begin{array}{l}\text { Hac1 Arif } \\
\text { Bey }\end{array}$ & Karciğar & Şark1 & $\begin{array}{l}\text { Türk } \\
\text { Aksağ } 1\end{array}$ & 285 & 10944 \\
\hline 291 & $\begin{array}{l}\text { Vay ne müşkülmüş } \\
\text { güzel sevmek meğer }\end{array}$ & Civan Ağa & Kürdîlihicazkâr & Şark1 & Curcuna & 116 & 10956 \\
\hline 292 & $\begin{array}{l}\text { Vuslatından gayrı el } \\
\text { çektim yeter ey } \\
\text { bîvefâ }\end{array}$ & $\begin{array}{l}\text { Hac1 Arif } \\
\text { Bey }\end{array}$ & Rast & Şark1 & Katakofti & 35 & 11000 \\
\hline 293 & $\begin{array}{l}\text { Yâd edib azar çürük } \\
\text { nazlı yâram } \\
\text { ağlarım }\end{array}$ & $\begin{array}{l}\text { Ahmet } \\
\text { Efendi }\end{array}$ & Sûzinak & Şark1 & $\begin{array}{l}\text { A } \breve{g} 1 \mathrm{r} \\
\text { Aksak }\end{array}$ & 63 & - \\
\hline 294 & $\begin{array}{l}\text { Yandı dil aşkınla ey } \\
\text { şûh-i şenim }\end{array}$ & Nikoğos Ağa & Acem Aşîran & Şark1 & $\begin{array}{l}\text { Ağır } \\
\text { Aksak }\end{array}$ & 327 & 11129 \\
\hline 295 & $\begin{array}{l}\text { Yandım âteşlere ey } \\
\text { meh seni gördüm } \\
\text { göreli }\end{array}$ & Faiz Bey & Uşşak & Şark1 & Aksak & 134 & 11131 \\
\hline 296 & $\begin{array}{l}\text { Y1kma sakın burc-1 } \\
\text { penâhım felek }\end{array}$ & $\begin{array}{l}\text { Hacı Arif } \\
\text { Bey }\end{array}$ & Karciğar & Şark1 & $\begin{array}{l}\text { Sengin } \\
\text { Semâî }\end{array}$ & 290 & 11339 \\
\hline 297 & $\begin{array}{l}\text { Yine bir gül-nihâl } \\
\text { aldı bu gönlümü }\end{array}$ & Dede Efendi & Rast & Şark1 & Curcuna $^{171}$ & 31 & 11439 \\
\hline 298 & $\begin{array}{l}\text { Yoktur zaman gel } \\
\text { mâhım heman gel }\end{array}$ & Latif Efendi & Hicazkâr & Şark1 & Curcuna $^{172}$ & 119 & 11530 \\
\hline 299 & $\begin{array}{l}\text { Yürek yâre ciğerim } \\
\text { oldu pâre pâre }{ }^{173}\end{array}$ & - & Hicaz & Şark1 & Aksak & 194 & - \\
\hline 300 & $\begin{array}{l}\text { Yüzündür cihanı } \\
\text { münevver eden }\end{array}$ & Dede Efendi & Rast & Şark1 & $\begin{array}{l}\text { Yürük } \\
\text { Semâî }\end{array}$ & 22 & 11622 \\
\hline 301 & $\begin{array}{c}\text { Zannım bu ki cânâ } \\
\text { beni kurban } \\
\text { edeceksin }\end{array}$ & Şevki Bey & Hicaz & Şark1 & Aksak & 189 & 11660 \\
\hline 302 & $\begin{array}{c}\text { Zâr oldu gönül } \\
\text { nazra-i sûziş } \\
\text { eserinden }\end{array}$ & $\begin{array}{l}\text { Kanûnî Gâlip } \\
\text { Efendi }\end{array}$ & Sûzinak & Şark1 & Curcuna & 81 & 11661 \\
\hline 303 & $\begin{array}{l}\text { Zâtını tebrik edib } \\
\text { tanzim için ey } \\
\text { şehriyâr }^{174}\end{array}$ & Şevki Bey & - & - & Düyek & 106 & - \\
\hline 304 & $\begin{array}{l}\text { Zeliha'm meni } \\
\text { yıkdın güzelim tâ } \\
\text { temelimden }\end{array}$ & & & Gazel & & 374 & \\
\hline 305 & $\begin{array}{l}\text { Zülfüne dil-besteler } \\
\text { zülf-i perîşânın kadar }\end{array}$ & Asdik Efendi & Hicaz & Şark1 & $\begin{array}{l}\text { Ağır } \\
\text { Aksak }\end{array}$ & 183 & 11727 \\
\hline 306 & $\begin{array}{l}\text { Zülfünü görsem } \\
\text { izârın üzre ey hur-i } \\
\text { cemil }\end{array}$ & Rif'at Efendi & Uşşak & Beste & Çenber & 123 & 11729 \\
\hline 307 & $\begin{array}{c}\text { Zümre-i hûbân } \\
\text { içinde pek beğendim } \\
\text { ben seni }\end{array}$ & Rizâ Efendi & Rast & Şark1 & $\begin{array}{l}\text { A ğır } \\
\text { Aksak }\end{array}$ & 6 & 11737 \\
\hline
\end{tabular}

${ }^{170}$ Eser TRT Nota Arşivinde kayıtlı değildir.

${ }^{171}$ Eser TRT Nota Arşivinde semâî olarak kayıtlıdır.

172 Eser TRT Nota Arşivinde semâî olarak kayıtlıdır.

173 TRT Nota Arşivinde kaydı bulunmamaktadır.

${ }^{174}$ Eser mecmua içerisinde hicazkâr-1kürdî faslı içerisinde kayıtlıdır. TRT Nota Arşivinde kaydı bulunmamaktadır. Eserin notasına ulaşamamıș olmamız ayrıca kürdîlihicazkâr ve hicazkâr makamlarının bir arada verilmesi sebebi ile de eserin makamı tespit edilememiştir. 


\section{Sonuç}

Güfte mecmuaları Tarihsel Müzikoloji içerisinde yer alan önemli mûsikî kaynaklarıdır. İçerisinde, yazıldığı dönemin mûsikî kültürü hakkında kıymetli ipuçları barındırır. Bestekârlar, güftekârlar, nazarî bilgiler yanında dönemde kullanılan usûller, makamlar hakkında da bizlere bilgiler sunar. Bununla birlikte yazılmış olduğu dönemin yalnızca mûsikî kültürü hakkında değil aynı zamanda edebiyatı, tarihi ve diğer sanatlarla olan ilişkisinin ortaya konması açısından bilgiler veren kıymetli kaynaklardır. Güfte mecmuaları repertuvar kültürü içerisinde özellikle güfte açısından ne tür değişimlerin yaşanmış olduğunu ortaya koyan kaynakların da başında gelmektedir.

Mecmua içerisinde yalnızca güfte, makam, usûl ve bestekâr isimleri mevcut olup çalışma içerisinde zikredilen farklı herhangi bir bilgi yer almamıştır. Makamlara ilişkin sonuçlarda 11 makam kullanılmış olup yegâh makamı başlığ 1 kaydedilmesine karşın boş bırakılmıştır. En çok güftenin yer aldığı makam 55 makam ile hicaz makamı olmuştur. Mecmua içerisinde yer alan makamlar tarafımızdan döneminin gözde makamları olarak nitelendirilmiştir. Usûllere ilişkin sonuçlarda 14 farklı usûlün yer aldığı mecmuada en çok 136 adet aksak usûllü esere yer verilirken en az 3 adet semâî usûllü esere yer verilmiştir. Mûsikî formlarına ilişkin sonuçlarda 281 şarkı formu yanında beste, yürüksemâî, gazel gibi formlara da yer verilmiş olduğu tespit edilmiştir. Mecmuada en fazla bestesi kayıtlı olan Şevki Bey’i (37) Hacı Arif Bey (30) izlemiştir. Tokat Mevlevîhane Müzesinde yer alan mecmuanın yazım tarihi için envanter kayıt defterine 1845 yılı düşülmüştür. Ancak Şevki Bey'in doğum tarihi (1860) göz önüne alındığında bu tarihin mümkün olmadığı görülmekte, 1845 tarihi düşülürken içeride yer alan h.25 Nisan 1331 tarihinin gözden kaçmış olduğu düşünülmektedir.

Döneminin mûsikî kültürünü bizlere ulaştırmak isteyen, yurt içinde ve yurt dişında yer alan kütüphanelerde bulunan daha birçok güfte mecmuasının olduğu bilinmektedir. Sistemli bir çalışma ile bu mecmualara ulaşılması ve ait oldukları topraklara kavuşturulmaları önemlidir. Birçok kütüphanede mevcut olan güfte mecmualarının birçoğu iyi muhafaza edilememiş olmaları sebebi ile gerek nemden dolayı mürekkep akmaları, küflenme, aşınma gerekse böcek 1sırıkları gibi bazı fiziki sorunlarla karşı karşıya kalmakta ve kâğıt konservasyonuna ihtiyaç duymaktadır. Bu eserlere gösterilecek gerekli ilginin Türk mûsikîsinin zengin kültürüne gerek repertuvar gerekse nazari anlamda daha fazla katkı sağlanacağı aşikârdır.

\section{Kaynakça}

Behar, C. (2006). Aşk olmayınca meşk olmaz. Yapı Kredi Yayınları.

Öztuna, Y. (2000). Türk musikisi kavram ve terimleri ansiklopedisi. Atatürk Kültür Merkezi Yayınları.

Parmaksız, M. N. (2016). Bodleian kütüphanesi 127-128 numaralı Türk musikisi güfte mecmuasının incelenmesi, [yayınlanmamış doktora tezi]. Gazi Üniversitesi Güzel Sanatlar Enstitüsü.

Soysal, F., \& Uğurlu, A. M. (2014). 1774 tarihli Hâfız Abdülbâkî’ye ait güfte mecmuasının incelenmesi. Rast Müzikoloji Dergisi, $\quad$ II $\quad$ (1), https://doi.org/10.12975/rastmd.2014.02.01.00021

Uslu, R. (2000). Türk müziği eğitim tarihinde güfte mecmualarl ve incelenme esaslarl üzerine tespitler. Müzikte 2000 Sempozyumu, 17-18 Mayıs, Ankara.

Uz, K. (1967). Musiki ıstılâhatı. Küğ Yayınları.

Uzun, M. (2003). Mecmua. Diyanet vakfi islam ansiklopedisi içinde, (Cilt 28, ss. 265). Diyanet İslam Ansiklopedisi.

https://www.notaarsivleri.com/eskisite/Turk_Sanat_Muzigi.html 